OPEN ACCESS

Edited by:

Naser A. Anjum,

Aligarh Muslim University, India

Reviewed by:

Anket Sharma,

Zhejiang Agriculture and Forestry

University, China

Xiancan Zhu,

Anhui Normal University, China Mohammed Mohammed El Hawary, Field Crop Research Institute, Egypt

*Correspondence:

Mohammad Sohidul Islam

shahid_sohana@yahoo.com

Ayman El Sabagh

ayman.elsabagh@agr.kfs.edu.eg

Specialty section:

This article was submitted to

Plant-Soil Interactions,

a section of the journal

Frontiers in Agronomy

Received: 20 August 2020 Accepted: 04 December 2020

Published: 05 January 2021

Citation:

Islam MS, Hasan MK, Islam B, Renu NA, Hakim MA, Islam MR, Chowdhury MK, Ueda A, Saneoka H,

Ali Raza M, Fahad S, Barutçular C, Çig F, Erman $M$ and EI Sabagh A (2021) Responses of Water and

Pigments Status, Dry Matter Partitioning, Seed Production, and Traits of Yield and Quality to Foliar

Application of $\mathrm{GA}_{3}$ in Mungbean (Vigna radiata L.).

Front. Agron. 2:596850.

doi: 10.3389/fagro.2020.596850

\section{Responses of Water and Pigments Status, Dry Matter Partitioning, Seed Production, and Traits of Yield and Quality to Foliar Application of $\mathrm{GA}_{3}$ in Mungbean (Vigna radiata L.)}

\begin{abstract}
Mohammad Sohidul Islam ${ }^{1 *}$, Md. K. Hasan ${ }^{1}$, Bushra Islam ${ }^{1}$, Nowrin Akhter Renu ${ }^{1}$, Mohammad A. Hakim ${ }^{2}$, Mohammad Rafiqul Islam³ ${ }^{3}$ M. Kaium Chowdhury ${ }^{4}$, Akihiro Ueda ${ }^{5}$, Hirofumi Saneoka ${ }^{5}$, Muhammad Ali Raza ${ }^{6}$, Shah Fahad ${ }^{7}$, Celaleddin Barutçular ${ }^{8}$, Fatih Çig $^{9}$, Murat Erman ${ }^{9}$ and Ayman El Sabagh ${ }^{9,10 *}$

${ }^{1}$ Department of Agronomy, Hajee Mohammad Danesh Science and Technology University, Dinajpur, Bangladesh, 2 Department of Agricultural Chemistry, Hajee Mohammad Danesh Science and Technology University, Dinajpur, Bangladesh, ${ }^{3}$ Agronomy Division, Regional Agricultural Research Station, Bangladesh Agricultural Research Institute, Pabna, Bangladesh, ${ }^{4}$ Department of Agricultural Extension, Agricultural Training Institute, Gaibandha, Bangladesh, ${ }^{5}$ Graduate School of Integrated Sciences for Life, Hiroshima University, Hiroshima, Japan, ${ }^{6}$ College of Agronomy, Sichuan Agricultural University, Chengdu, China, ${ }^{7}$ Agriculture Department, The University of Swabi, Swabi, Pakistan, ${ }^{8}$ Department of Field Crops, Faculty of Agriculture, University of Cukurova, Adana, Turkey, ${ }^{9}$ Department of Field Crops, Faculty of Agriculture, Siirt University, Siirt, Turkey, ${ }^{10}$ Department of Agronomy, Faculty of Agriculture, Kafrelsheikh University, Kafr El-Shaikh, Egypt
\end{abstract}

This study evaluated the role of gibberellic acid [GA $A_{3} ;(0,100,200$, and 300 ppm)] in modulation of the growth, physiology, yield, and quality traits in two varieties (BARI Mung- 6 and BARI Mung-8) of mungbean (Vigna radiata L.). Irrespective of the two varieties (BARI Mung-6 and BARI Mung-8), 100, 200, and 300 ppm of $\mathrm{GA}_{3}$ differentially modulated the tested parameters (relative water content, RWC; photosynthetic pigments: chlorophyll a, chlorophyll b, and carotenoids; growth parameters: fresh and dry weights of leaves, petioles, stems, and roots; yield contributing traits such as plant height, number of pods plant ${ }^{-1}$, number of grains pod ${ }^{-1}$, pod length, and 100-grain weight; quality traits such as grain nitrogen and protein). However, compared to the lowest $\mathrm{GA}_{3}(100 \mathrm{ppm})$ and the highest $\mathrm{GA}_{3}(300 \mathrm{ppm})$, the moderate concentration of $\mathrm{GA}_{3}(200 \mathrm{ppm})$ led to highest values of leaf-RWC, where this parameter exhibited 16.1 and $13.4 \%$ increase in BARI Mung-8 and BARI Mung-6, respectively. Similarly, the tested herein growth parameters and the yield traits significantly increased up to the foliar application of the moderate $\mathrm{GA}_{3}$ concentration (200 ppm), and thereafter these traits decreased with 300 ppm GA $\mathrm{G}_{3}$. The 200 ppm-led changes in the growth and yield traits were significantly higher in BARI Mung-8 when compared to BARI Mung-6. Considering the quality traits, $\mathrm{GA}_{3}$ positively influenced the nitrogen and protein content in grains, where 200 ppm of $\mathrm{GA}_{3}$ led to increases of $25.2 \%$ in $\mathrm{N}$, and $17.7 \%$ in protein over control in BARI Mung-6; whereas, BARI Mung-8 exhibited $28.3 \%$ in $\mathrm{N}$, and $18.3 \%$ in protein with 200 ppm GA $\mathrm{G}_{3}$ over control. Overall, BARI Mung-8 significantly responded to the foliar supply of 200 ppm $\mathrm{GA}_{3}$ when compared to BARI Mung-6. Hence, in order to high 
yield and grain protein content, the application of 200 ppm $\mathrm{GA}_{3}$ may be applied in $V$. radiata before and during flowering. The major mechanisms underlying the responses of the water relation, growth, and yield traits to the $\mathrm{GA}_{3}$ concentrations need to be explored.

Keywords: physiology, growth, yield, protein content, gibberellic acid, mungbean

\section{INTRODUCTION}

Pulses are rich in protein, and contain more than three times higher quality protein than cereals. In addition, pulse crops preserve, and improve soil fertility through biological nitrogen fixation (BNF) in soil and hence, contribute a significant role in sustainable agriculture. Pulses are popularly known as the "poor man's meat" in most of the developing countries due to cheaper and availability than animal protein. Mungbean [Vigna radiata (L.) R. Wilczek] is an important pulse crop all over the world with an admirable economic importance. The grains of mungbean contain $25.67 \%$ protein, $1-3 \%$ fat, $5.4 \%$ carbohydrates, $3.5-4.5 \%$ fibers, and $4.5-5.5 \%$ ash with very low amount of flatulence effects (Frauque et al., 2000; Ahmad et al., 2008), and rich in folate and iron (Noble et al., 2018). It is an antique crop in Bangladesh with dietary and nutritional value (Islam et al., 2017c). It is a vital crop to the small land-holdings Asian farmers, and is consumed as a soup of split seeds and spices called Dal or Dhal. It is easily digestible, and does not have any adverse effect on human bodies. It ranks 3rd position next to lentil and grasspea both in acreage and production in Bangladesh [Agriculture Information Service (AIS), 2019]. The area and production of mungbean is gradually decreasing regrettably [Agriculture Information Service (AIS), 2019], and it is indispensable to produce extra food from decreasing agricultural land area for mitigating the appropriate food requirements (Islam et al., 2017a,b). The crop fits well in multi-cropping systems, because of its rapid growth and early maturity. Since, the crop is widely grown in marginal and abiotically stressed agro-ecosystems (Raina et al., 2016), but it experiences a considerable yield losses. Total pulses production must be increased urgently to meet the consumption and protein demand. Due to lack of high yielding variety and proper production technology, the yield of mungbean is very low in Bangladesh as compared to other mungbean producing countries. BARI Mung- 6 and BARI Mung- 8 are the high yielding varieties but the yield in the farmers' field is very low as compared to their yield potential. Various management practices may help to achieve the desired yield potential of mungbean, and plant growth regulators (PGRs) application in different techniques seem to be the most significant one in view of cost and labor efficacy.

Gibberellic acid $\left(\mathrm{GA}_{3}\right)$ is an important PGR which enhances the growth, development, and yield of different crops. $\mathrm{GA}_{3}$ is a phyto-hormone, and terpenoid compounds containing 19-20 carbon atoms, naturally produced in new leaves and germinated seed embryos, and more than 136 species have been identified (Sponsel and Hedden, 2004). Very small amount of $\mathrm{GA}_{3}$ enhances stem elongation (Abd El-Fattah, 1997; Hoque and Haque, 2002; Abdel and Al-Rawi, 2011; Keykha et al., 2014) by increasing cell divisions and cell size (Taiz and Zeiger, 2006,
2010), improves plant growth and development (Kundu et al., 2017; Rahman et al., 2018) by inducing metabolic activities (Kumar et al., 2014; Singh et al., 2015), many key enzymes like carbonic anhydrase (CA), nitrate reductase (NR) (Afroz et al., 2005; Aftab et al., 2010; Ahmad Dar et al., 2015), ribulose1, 5-biphosphate carboxylase/oxygenase (RuBPCO) (Yuan and $\mathrm{Xu}, 2001$ ), and regulating nitrogen utilization (Siddiqui et al., 2008; Khan et al., 2010; Sure et al., 2012; Zhang et al., 2017; Miceli et al., 2019), consequently increases dry weight and yield (Asahina et al., 2002; Tasnim et al., 2020). It also induces growth and development by enhancing water uptake in plant tissues (Al-Whaibi et al., 2010; Maggio et al., 2010; Renu, 2019), photosynthetic pigments (El Karamany et al., 2019), photosynthesis (Khan et al., 2002; Aftab et al., 2010), sex determination (Fleet and Sun, 2005), flower formation and fruit set in legumes (Deotale et al., 1998; Chauhan et al., 2010), and hence amplifies yield of many crops (Bhadra, 2004; Bora and Sharma, 2006; Abdel-Mouty and El-Greadly, 2008; Faizanullah et al., 2010; Rastogi et al., 2013; Keykha et al., 2014). It has also been evidenced that $\mathrm{GA}_{3}$ assists to maintain water status in plants under salinity/drought mediated water deficit stress (Hossain et al., 2015; Nehal et al., 2018), enhances stress tolerance and pathogenic defense (Maggio et al., 2010; Soliman, 2020).

However, exogenous application of $\mathrm{GA}_{3}$ on several other crops has been previously studied but no updated and precise information is available regarding the effects $\mathrm{GA}_{3}$ on the morpho-physiology and quality traits of Vigna radiata in home and abroad. Now, the challenge is to find the ways and means for increasing productivity of Vigna radiata genotypes. Our study concerning responses of water and photosynthetic pigments status, dry matter partitioning, seed production, and traits of yield and quality to foliar application of $\mathrm{GA}_{3}$ in Vigna radiata varieties may lead to provide useful information for increasing productivity worldwide. In view of the above back ground, the present investigation was undertaken to assess the effects of $\mathrm{GA}_{3}$ by different concentrations on the water status, photosynthetic pigments, dry matter partitioning, yield and quality of Vigna radiata, and to find out the optimum concentration of $\mathrm{GA}_{3}$ and suitable variety for higher yield.

\section{MATERIALS AND METHODS}

\section{Location and Duration}

The study was designed and conducted at the Crop Museum, Department of Agronomy, Hajee Mohammad Danesh Science and Technology University, Dinajpur, Bangladesh. The geographical position of the area is between $25^{\circ} 44.574^{\prime \prime} \mathrm{N}$ and $88^{\circ} 40.344^{\prime \prime} \mathrm{E}$, and $40 \mathrm{~m}$ above sea level. The Agro Ecological Zone (AEZ) of the area is the Old Himalayan Piedmont 


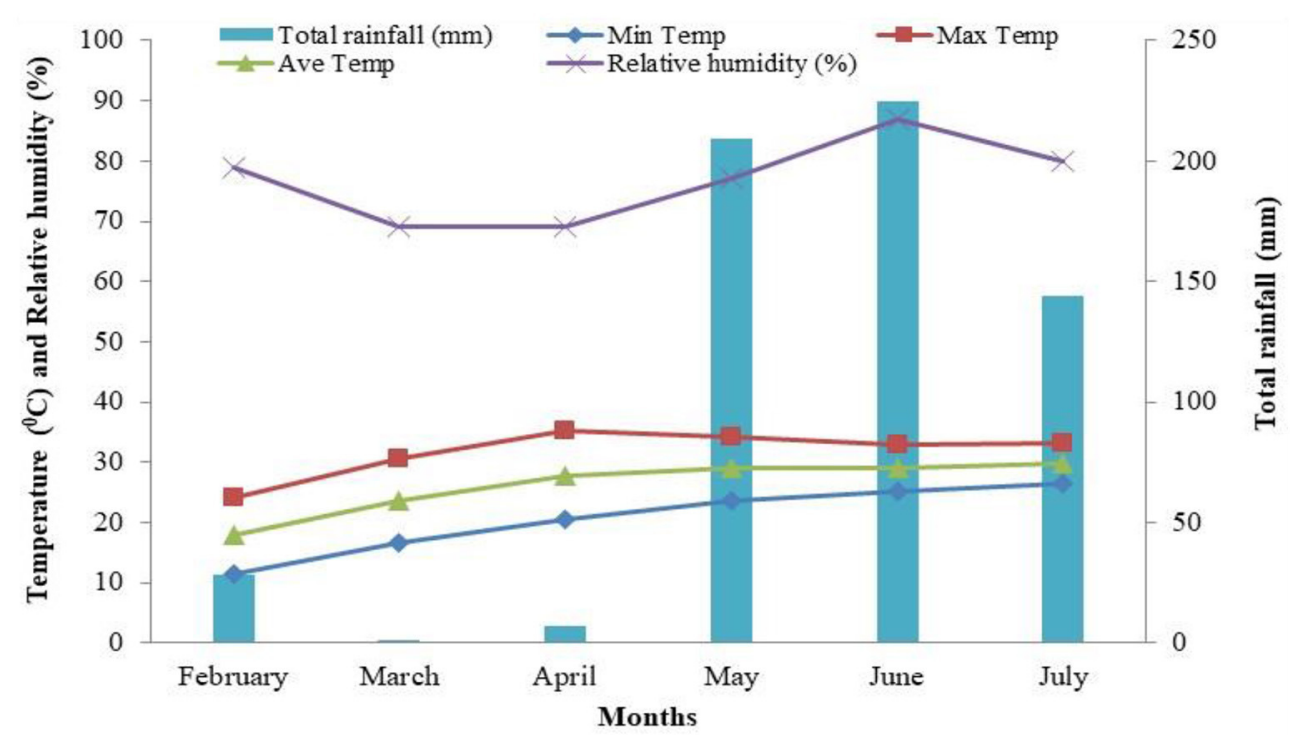

FIGURE 1 | Monthly average temperature (minimum, maximum, and mean), relative humidity (\%), and rainfall (mm) during the experiment.

Plain (AEZ-1) [Fertilizer Recommendation Guide (FRG), 2012]. The experiment was completed within the period of February-May 2018.

\section{Weather Conditions}

Weather data on weekly average temperature, humidity, and rainfall during the research period were recorded regularly by the HOBO U12 Family of Data Loggers (MicroDAQ.com) at the meteorological station of HSTU, Dinajpur. The data regarding average temperature (maximum, minimum, and mean), humidity, and rainfall during the experimentation are presented in Figure 1.

\section{Soil Properties}

The soil of the experiment was analyzed before sowing of $V$. radiata, and it was sandy loam having very poor nutrients status. The total soil $\mathrm{N}$ was $0.08 \%$, indicating a deficiency in soil $\mathrm{N}$. The available $\mathrm{K}$ was $0.10 \mathrm{meq} 100 \mathrm{~g}^{-1}$ soil, and available P, S, B, Zn, were $11.2,7.29,0.13$, and $0.90 \mathrm{ppm}$, respectively. Based on the critical value, the content of $\mathrm{N}$, $\mathrm{S}$, and $\mathrm{B}$ were low; but $\mathrm{P}, \mathrm{K}$, and $\mathrm{Zn}$ were high in the experimental soil. The organic matter content and soil $\mathrm{pH}$ values were $1.48 \%$ and 5.41 , respectively. The morphological, physical and chemical properties of the soil are presented in the Table 1.

\section{Plant Materials}

BARI Mung-6 $\left(\mathrm{V}_{1}\right)$ and BARI Mung- $8\left(\mathrm{~V}_{2}\right)$ were used in this study. The seeds of high yielding $V$. radiata varieties were obtained from Pulse Research Center, Regional Agricultural Research Station (Bangladesh Agricultural Research Institute, BARI), Ishurdi, Pabna, Bangladesh. Both varieties are very popular due to their unique properties like they can be grown in the year round
(Rabi, Kharif-1, and Kharif-2 seasons). The comparative properties of $V$. radiata varieties are presented in Table 2.

\section{Gibberellic Acid}

Gibberellic acid $\left(\mathrm{GA}_{3}\right)$ was used as PGR, and it is a plant hormone stimulating plant growth and development, which has a tetra cyclic di-terpenoid compound, shown in Figure 2.

\section{Treatments and Experimental Design}

The research work was comprised as two factors naming four levels of $\mathrm{GA}_{3}(0,100,200$, and $300 \mathrm{ppm})$, and two $V$. radiata varieties naming BARI Mung-6 and BARI Mung-8. The research area was divided into 3 blocks, each block was subdivided into eight plots, and size of each plot was $3 \mathrm{~m} \times 2 \mathrm{~m}\left(6.0 \mathrm{~m}^{2}\right)$. The study was laid out in Randomized Complete Block Design (RCBD) with three replications.

\section{Experimentation}

In experimental site, the land was first plowed thoroughly, fertilized with the recommendation of [Bangladesh Agricultural Research Institute (BARI), 2019] and prepared the land ready for seed sowing. The seeds were sown at mid-February with a spacing of $30 \mathrm{~cm} \times 5 \mathrm{~cm}$ maintaining required moisture conditions. All intercultural operations are done properly equally for better growth and development. Treatments of $\mathrm{GA}_{3}$ were prepared according to the treatments specification (100,200, and $300 \mathrm{ppm}$ concentration), and applied on the plant foliage twice at 25 days after sowing (DAS) i.e., before flowering stage and at 35 DAS i.e., at flowering stage. 
TABLE 1 | Morphology, physical and chemical properties of the soil of the research field, HSTU, Dinajpur, with the critical value and extraction method.

\begin{tabular}{|c|c|c|c|}
\hline Parameter & & & Properties \\
\hline \multicolumn{4}{|c|}{ Morphological soil properties } \\
\hline AEZ & \multicolumn{3}{|c|}{ AEZ-1: Old Himalayan Piedmont Plain } \\
\hline Land type & \multicolumn{3}{|l|}{ Highland } \\
\hline General soil type & \multicolumn{3}{|c|}{ Non-calcareous, brown floodplain soil } \\
\hline Soil series & \multicolumn{3}{|l|}{ Ranisankil } \\
\hline Topography & \multicolumn{3}{|l|}{ Leveled } \\
\hline Drainage & \multicolumn{3}{|c|}{ Good drainage system } \\
\hline Flood level & \multicolumn{3}{|c|}{ Above flood level } \\
\hline Geographic position & \multicolumn{3}{|c|}{$25.44^{\circ}$ North Latitude, $88.40^{\circ}$ East Longitude, $37.35 \mathrm{~m}$ above sea level } \\
\hline Property & Value (\%) & Critical value & Extraction method \\
\hline \multicolumn{4}{|l|}{ Physical soil properties } \\
\hline Sand & 58 & - & - \\
\hline Silt & 28 & - & - \\
\hline Clay & 14 & - & - \\
\hline Textural class & Sandy loam & - & $\begin{array}{l}\text { Hydrometer method (Black, 1965). Determined by Marshall's triangular } \\
\text { coordinates by USDA system }\end{array}$ \\
\hline Property & Value & Critical value & Extraction method \\
\hline \multicolumn{4}{|l|}{ Chemical soil parameters } \\
\hline Soil pH (1:1.25, Soil: $\left.\mathrm{H}_{2} \mathrm{O}\right)$ & 5.41 & - & Glass-electrode pH meter with 1:1.25 soil-water ratios (Page et al., 1982). \\
\hline Organic matter & 1.48 & - & $\begin{array}{l}\text { Wet oxidation method (Black, 1965). Calculated by Van Bemmelen factor } \\
1.73 \text { (Piper, 1966). }\end{array}$ \\
\hline$N(\%)$ & 0.08 & 0.10 & Micro-Kjeldahl method (Bremner and Mulvaney, 1982). \\
\hline Available P (ppm) & 11.20 & 8.00 & Molybdate blue ascorbic acid (Bray and Kurtz, 1945). \\
\hline Exchangeable K (meq \%) & 0.10 & 0.08 & Determined by flame photometer \\
\hline Available S (ppm) & 7.29 & 8.00 & Turbidity method using $\mathrm{BaCl}_{2}$ (Fox et al., 1964). \\
\hline Available B (ppm) & 0.13 & 0.16 & Calcium chloride extraction method (Page et al., 1982). \\
\hline Available Zn (ppm) & 0.90 & 0.50 & Atomic absorption spectrophotometer (Lindsay and Norvell, 1978). \\
\hline
\end{tabular}

TABLE 2 | Properties of existing V. radiata varieties used in the present experiment [Bangladesh Agricultural Research Institute (BARI), 2019].

\begin{tabular}{|c|c|c|c|c|c|c|}
\hline Varieties & Year of release & $\begin{array}{l}\text { Life span } \\
\text { (days) }\end{array}$ & Plant height (cm) & 1,000-grain weight $(g)$ & Yield $\left(\right.$ tha $\left.^{-1}\right)$ & Major diseases and pests \\
\hline BARI Mung-6 & 2003 & $55-58$ & $40-45$ & $51-52$ & $1.5-1.6$ & Highly tolerant to leaf spot and yellow mosaic virus \\
\hline BARI Mung-8 & 2015 & $60-62$ & $55-60$ & 30-32 & $1.6-1.7$ & Highly tolerant to leaf spot and yellow mosaic virus \\
\hline
\end{tabular}

\section{Data Collection}

\section{Growth, Plant Biomass, Yield Traits, and Yield}

The first sampling was done at 40 DAS for measuring fresh and dry weight of leaves, petioles, stems, and roots. The final data was taken at the harvesting time. The following parameters e.g., plant height $(\mathrm{cm})$, number of pods plant ${ }^{-1}$, number of grain $\operatorname{pod}^{-1}$, pod length $(\mathrm{cm})$, thousand grain weight $(\mathrm{g})$, grain yield $\left(\mathrm{tha}^{-1}\right)$, stover yield $\left(\right.$ tha $^{-1}$ ), and harvest index (\%) were taken. Harvest index was calculated by dividing the economic yield (seed) from the net plot by the total biological yield (seed yield + stover yield) from the same area and multiplying by 100 according to Donald (1963).

Harvest index $(\%)=($ Grain yield $/$ Biological yield $) \times 100$.

\section{Relative Water Content}

The relative water content (RWC) was measured at 40 DAS by fresh weight basis. Fully expanded third trifoliate leaves from top were taken. The leaves were kept immersed in distilled water for $24 \mathrm{~h}$ at room temperature in the dark. The turgid weights of those plant parts were measured, and afterwards all the materials were oven-dried at $80^{\circ} \mathrm{C}$ for $72 \mathrm{~h}$ to take dry weight. The values of the fresh, turgid and dry weights of the leaves were used to calculate RWC according to the following formulae used by Barr and Weatherley (1962). The RWC expresses as percentage.

$$
\begin{aligned}
& \text { Relative Water Content }(\text { RWC) }= \\
& \qquad \frac{\text { Fresh weight }- \text { Dryweight }}{\text { Turgid weight }- \text { Dryweight }} \times 100 .
\end{aligned}
$$




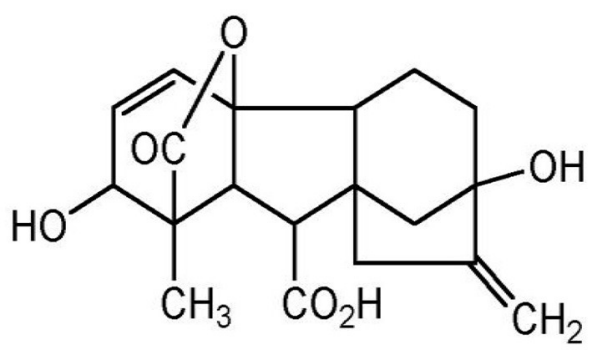

FIGURE 2 | Chemical structure of $\mathrm{GA}_{3}$.

\section{Determination of Photosynthetic Pigments}

Photosynthetic pigments (chlorophyll a and b, and carotenoids) contents in fresh leaves were estimated at 45 DAS on fresh weight basis extracting the leaf samples with $80 \%$ acetone using a spectrophotometer (Spectronic UV-1700, Shimadzu, Japan). The reading of the solution (optical density) was recorded at 645 and $662 \mathrm{~nm}$ for chlorophylls, and at $470 \mathrm{~nm}$ for carotenoids, and calculated using the method of Lichtenthaler and Buschmann (2001). The values of photosynthetic pigments were expressed in $\mathrm{mg} \mathrm{g}^{-1} \mathrm{FW}$.

\section{Determination of Nitrogen and Protein Content of Mungbean Seeds}

Nitrogen content in grains was determined by Micro-Kjeldahl method (Bremner and Mulvaney, 1982). The actual nitrogen values in the sample were calculated from the standard curve and expressed as percentage. The protein content of seed samples was determined by using method of Thaltooth et al. (2006) and Yagoob and Yagoob (2014), and expressed as percentage.

Seed protein content $(\%)=$ Total nitrogen $(\%) \times 6.25$

\section{Data Analysis}

To analyze the collected data and all parameters MSTATC program (One-way ANOVA) was used in computer and presented as mean $\pm \mathrm{SE}(n=3)$. Data were adjusted by Duncan's Multiple Range Test (DMRT) at 5\% level of probability (Gomez and Gomez, 1984).

\section{RESULTS AND DISCUSSION}

\section{Physiological Traits}

\section{Relative Water Content (\%)}

Exogenous application of $\mathrm{GA}_{3}$ significantly and positively influenced the RWC in the leaves of $V$. radiata varieties in this study (Table 3). However, $\mathrm{GA}_{3}$ application increased the RWC as compare to control, and the highest RWC (85.52 and $88.35 \%$ ) was recorded with the 200 ppm of $\mathrm{GA}_{3}$ in BARI Mung-6 and BARI Mung- 8 , respectively. BARI Mung- 8 contained higher RWC than BARI Mung- 6 under all $\mathrm{GA}_{3}$ levels. The increment rates due to foliar application of 100, 200, and 300 ppm GA were $7.9,13.4$, and $7.1 \%$ in BARI Mung-6, and 9.2, 16.1, and $10.6 \%$ in BARI Mung-8, respectively. The results of our study were strongly supported by Renu (2019), who reported that 200
TABLE 3 | Effect of $\mathrm{GA}_{3}$ on the relative water content (\%) in the leaves of $V$. radiata varieties.

\begin{tabular}{|c|c|c|c|c|}
\hline \multirow[t]{2}{*}{$\mathrm{GA}_{3}(\mathrm{ppm})$} & \multicolumn{4}{|c|}{ Relative water content (\%) } \\
\hline & $\begin{array}{c}\text { BARI } \\
\text { Mung-6 }\end{array}$ & $\begin{array}{c}\text { Increase over } \\
\text { control }(\%)\end{array}$ & $\begin{array}{c}\text { BARI } \\
\text { Mung-8 }\end{array}$ & $\begin{array}{c}\text { Increase over } \\
\text { control (\%) }\end{array}$ \\
\hline 0 & $\begin{array}{c}75.40 c \\
(0.58)\end{array}$ & - & $\begin{array}{c}76.10 c \\
(0.15)\end{array}$ & - \\
\hline 100 & $\begin{array}{c}81.35 b \\
(0.58)\end{array}$ & 7.9 & $\begin{array}{c}83.12 b \\
(0.58)\end{array}$ & 9.2 \\
\hline 200 & $\begin{array}{c}85.52 \mathrm{a} \\
(0.58)\end{array}$ & 13.4 & $\begin{array}{c}88.35 a \\
(0.15)\end{array}$ & 16.1 \\
\hline 300 & $\begin{array}{c}80.74 b \\
(0.15)\end{array}$ & 7.1 & $\begin{array}{c}84.16 b \\
(0.58)\end{array}$ & 10.6 \\
\hline CV (\%) & \multicolumn{4}{|c|}{4.63} \\
\hline
\end{tabular}

Data are presented as mean $\pm S E(n=3)$. Data followed by same letter are not significantly different by DMRT test at $p<0.05, \mathrm{CV}$, Co-efficient of variation.

ppm of $\mathrm{GA}_{3}$ maintained the highest value of RWC in $V$. radiata leaves. Several studies showed that exogenous application of $\mathrm{GA}_{3}$ remarkably increased the RWC in many crops such as faba bean (Al-Whaibi et al., 2010), chickpea (Hossain et al., 2015), wheat (Aldesuquy and Ibrahim, 2001; Hammad and Ali, 2014), maize (Kaya et al., 2006), sweet potato (El-Tohamy et al., 2015), cut flowers (Emongor, 2004), and Thymus vulgaris (Pazoki et al., 2012). Application of $\mathrm{GA}_{3}$ improved the root growth in our study (Tables 5, 6) which might help to uptake more water in plants. The increased water use efficiency due to $\mathrm{GA}_{3}$ might be revealed the encouraging effect of $\mathrm{GA}_{3}$ on both stomatal conductance and leaf area development (Miceli et al., 2019). Leaf stomatal conductance estimates the transpiration rates and gas exchange capacity through leaf stomata. Maggio et al. (2010) concluded that the stomatal resistance is decreased, and water use efficiency is increased in tomato plants due to exogenous application of $\mathrm{GA}_{3}$. It is also noted in previous studies that $\mathrm{GA}_{3}$ promotes to synthesize enzymes (invertase) that hydrolyze sucrose into glucose and fructose, thereby making water potential more negative in cells, which in turn results in increased water uptake by the cells (Salisbury and Ross, 1990; Jane, 2001).

\section{Photosynthetic Pigments}

Photosynthesis is the essential for plant growth, development, and yield of crops, and chlorophyll is one of the basic inputs for functioning photosynthesis. $\mathrm{GA}_{3}$ treatments caused a significant increase of the constituent of photosynthetic pigments (chlorophyll a, chlorophyll b, and carotenoids) as compared to control in both varieties, and BARI Mung- 8 showed higher values than in BARI Mung-6 (Table 4). However, foliar application of $\mathrm{GA}_{3}$ at $200 \mathrm{ppm}$ produced the highest amount of chlorophyll a, chlorophyll $b$, and carotenoids which were statistically similar to $300 \mathrm{ppm}$ of $\mathrm{GA}_{3}$. These results are supported by several studies reporting that $\mathrm{GA}_{3}$ enhanced the photosynthetic pigments in $V$. radiata (Mubeen et al., 2014; Baliah et al., 2018; El Karamany et al., 2019) as well as other crops like wheat (Pazuki et al., 2013), cotton (Onanuga et al., 2012; Firmino da Costa et al., 2017), Euphorbia lathyris (Garg and Kumar, 2012), Aloe barbadensis 
TABLE 4 | Effect of $\mathrm{GA}_{3}$ on the photosynthetic pigments ( $\mathrm{mg} \mathrm{g}^{-1}$ fresh weight) in the leaves of $V$. radiata varieties.

\begin{tabular}{|c|c|c|c|c|c|c|}
\hline \multirow[t]{2}{*}{$\mathrm{GA}_{3}(\mathrm{ppm})$} & \multicolumn{2}{|c|}{ Chlorophyll a } & \multicolumn{2}{|c|}{ Chlorophyll b } & \multicolumn{2}{|c|}{ Carotenoids } \\
\hline & $\begin{array}{c}\text { BARI } \\
\text { Mung-6 }\end{array}$ & $\begin{array}{c}\text { BARI } \\
\text { Mung-8 }\end{array}$ & $\begin{array}{c}\text { BARI } \\
\text { Mung-6 }\end{array}$ & $\begin{array}{c}\text { BARI } \\
\text { Mung-8 }\end{array}$ & $\begin{array}{c}\text { BARI } \\
\text { Mung-6 }\end{array}$ & $\begin{array}{c}\text { BARI } \\
\text { Mung-8 }\end{array}$ \\
\hline 0 & $\begin{array}{l}1.31 d \\
(0.06)\end{array}$ & $\begin{array}{l}1.67 \mathrm{c} \\
(0.12)\end{array}$ & $\begin{array}{l}0.73 c \\
(0.06)\end{array}$ & $\begin{array}{l}0.81 \mathrm{c} \\
(0.06)\end{array}$ & $\begin{array}{l}0.44 c \\
(0.03)\end{array}$ & $\begin{array}{l}0.52 c \\
(0.01)\end{array}$ \\
\hline 100 & $\begin{array}{l}1.93 c \\
(0.02)\end{array}$ & $\begin{array}{l}2.23 b \\
(0.06)\end{array}$ & $\begin{array}{c}0.89 b c \\
(0.03)\end{array}$ & $\begin{array}{l}0.98 b \\
(0.03)\end{array}$ & $\begin{array}{c}0.52 \mathrm{bc} \\
(0.05)\end{array}$ & $\begin{array}{l}0.61 b \\
(0.05)\end{array}$ \\
\hline 200 & $\begin{array}{l}2.17 b \\
(0.06)\end{array}$ & $\begin{array}{l}2.56 a \\
(0.06)\end{array}$ & $\begin{array}{c}1.11 \mathrm{ab} \\
(0.06)\end{array}$ & $\begin{array}{l}1.34 a \\
(0.06)\end{array}$ & $\begin{array}{c}0.69 \mathrm{ab} \\
(0.03)\end{array}$ & $\begin{array}{l}0.86 a \\
(0.02)\end{array}$ \\
\hline 300 & $\begin{array}{l}2.10 b \\
(0.06)\end{array}$ & $\begin{array}{c}2.37 a b \\
(0.06)\end{array}$ & $\begin{array}{l}1.03 b \\
(0.06)\end{array}$ & $\begin{array}{l}1.21 a \\
(0.06)\end{array}$ & $\begin{array}{c}0.67 a b \\
(0.03)\end{array}$ & $\begin{array}{l}0.89 a \\
(0.03)\end{array}$ \\
\hline CV (\%) & \multicolumn{2}{|c|}{5.32} & \multicolumn{2}{|c|}{2.36} & \multicolumn{2}{|c|}{7.85} \\
\hline
\end{tabular}

Data are presented as mean $\pm S E(n=3)$. Data followed by same letter are not significantly different by DMRT test at $p<0.05, \mathrm{CV}$, Co-efficient of variation.

(Sardoei, 2014), broccoli leaves (Hameed et al., 2015), and Simmondsia chinensis (Atteya et al., 2018). It has also been reported that exogenous application of $\mathrm{GA}_{3}$ modifies the specific constitution of plastids which is responsible for retention of chlorophyll (Ashour et al., 1973). Among all photosynthetic organisms, the carotenoids act as protecting "antenna pigments" for photosynthesis, gathering wavelengths of light that are not absorbed by chlorophylls (Vichnevetskaia and Roy, 1999). In fact, our results are consistent with previously reported findings that the $\mathrm{GA}_{3}$ enhanced the carotenoids contents in $V$. radiata (El Karamany et al., 2019), Artemisia annua (Aftab et al., 2010), rice (Ghodrat et al., 2013), corn (Al-Shaheen et al., 2014), Trigonella foenum-graecum (Ahmad Dar et al., 2015). It is suggested that the increase in carotenoid content by $\mathrm{GA}_{3}$ may be due to development of ultrastructural morphogenesis of plastids (Arteca, 1996). The increased contents of photosynthetic pigments (chlorophylls and carotenoids) owing to $\mathrm{GA}_{3}$ are responsible to increase the number and size of chloroplasts, enhance the activity of plastids (Arteca, 1996), Rubisco and photosynthetic $\mathrm{CO}_{2}$ assimilation rate (Taiz and Zeiger, 2006).

\section{Plant Growth Traits Leaf Fresh Weight}

Fresh weight of $V$. radiata leaves progressively increased with the application of $\mathrm{GA}_{3}$. In case of BARI Mung-8, significantly the highest leaf fresh weight $\left(6.17 \mathrm{~g} \mathrm{plant}^{-1}\right)$ was obtained by using 200 ppm of $\mathrm{GA}_{3}$ and the lowest weight (1.51 $\mathrm{g} \mathrm{plant}^{-1}$ ) was reported from control treatment i.e., 0 ppm of $\mathrm{GA}_{3}$ (Table 5). The enhancement of leaf area as well as leaf fresh weight has been demonstrated by Rahman et al. (2018) in V. radiata, and they concluded that $100 \mathrm{ppm} \mathrm{GA}_{3}$ as foliar application had produced highly significant values for obtaining the more leaf area comparatively than that of other foliar treatments. A similar conclusion was drawn from a very recent study by Renu (2019) who stated that $\mathrm{GA}_{3}$ at $200 \mathrm{ppm}$ increased the fresh weight of leaves plant ${ }^{-1}$ in $V$. radiata. Our results are also supported by Keykha et al. (2014) who noted that less concentration of $\mathrm{GA}_{3}$ (75 ppm) produced the highest forage yield of $V$. radiata. Area and number of leaves plant ${ }^{-1}$ was significantly increased with the application of $\mathrm{GA}_{3}$, and hence, $\mathrm{GA}_{3}$ of $33.3 \mathrm{ppm}$ produced the highest leaf area plant ${ }^{-1}$ in cow pea (Nabi et al., 2014), 50 ppm produced the highest number of leaves and thereafter decreased in $V$. radiata (Hoque and Haque, 2002) which were indirectly related in our result. $\mathrm{GA}_{3}$ apparently proved to increase the growth of leaves and reproductive organs through intermingling with other growth promoting hormones. In tobacco internodes, GA20-oxidase is the major target for auxin from the shoot apex (Wolbang and Ross, 2001), and it has been suggested that these increases in GA1 and GA4 are necessary for promoting inflorescence development.

\section{Petiole Fresh Weight}

The fresh weight of petiole in $V$. radiata was also observed as significant increase owing to $\mathrm{GA}_{3}$, and the highest $(0.44 \mathrm{~g}$ plant $\left.^{-1}\right)$ and lowest $\left(0.31 \mathrm{~g} \mathrm{plant}^{-1}\right)$ values were found at BARI Mung- 8 and BARI Mung- 6 by the application of $\mathrm{GA}_{3}$ at 200 and $0 \mathrm{ppm}$, respectively (Table 5). These results are consistent with previously reported information for $V$. radiata (Baliah et al., 2018; Renu, 2019), where $\mathrm{GA}_{3}$ remarkably increased the petiole fresh weight.

\section{Stem Fresh Weight}

Plant growth and development is considered as an index of yield. As a beginning of physiological process, adequate water absorption is required for plant fresh weight. The stem fresh weight of $V$. radiata varieties were significantly influenced by the application of $\mathrm{GA}_{3}$. Nonetheless, applying of $\mathrm{GA}_{3}$ at $200 \mathrm{ppm}$ gave the highest value of stem fresh weight $\left(1.83 \mathrm{~g} \mathrm{plant}^{-1}\right)$ in BARI Mung-8, while 0 ppm (control) gave the lowest value of stem fresh weight $\left(0.72 \mathrm{~g} \mathrm{plant}^{-1}\right)$ in BARI Mung-6 (Table 5). BARI Mung- 8 was more responsive to $\mathrm{GA}_{3}$ than BARI Mung6 in this study. Significant variation due to varieties was also obtained in respect of plant growth including stem fresh weight plant $^{-1}$. Rahman et al. (2018) noticed that foliar application of $100 \mathrm{ppm} \mathrm{GA} 3$ produced the highest plant growth (total biomass) in two $V$. radiata varieties of BARI Mung- 6 and BARI Mung5 , and the previous variety produced higher biomass than the later. In previous studies (Hedden and Phillips, 2000; Sevik and Guney, 2013), $\mathrm{GA}_{3}$ showed greater influence on many growth 
TABLE 5 | Effect of $\mathrm{GA}_{3}$ on the fresh weight in different plant parts of $V$. radiata varieties.

\begin{tabular}{|c|c|c|c|c|c|c|c|c|}
\hline \multirow[t]{2}{*}{$\mathrm{GA}_{3}(\mathrm{ppm})$} & \multicolumn{2}{|c|}{ Leaf fresh weight (g plant ${ }^{-1}$ ) } & \multicolumn{2}{|c|}{ Petiole fresh weight (g plant ${ }^{-1}$ ) } & \multicolumn{2}{|c|}{ Stem fresh weight (g plant ${ }^{-1}$ ) } & \multicolumn{2}{|c|}{ Root fresh weight (g plant ${ }^{-1}$ ) } \\
\hline & $\begin{array}{c}\text { BARI } \\
\text { Mung-6 }\end{array}$ & $\begin{array}{c}\text { BARI } \\
\text { Mung-8 }\end{array}$ & $\begin{array}{c}\text { BARI } \\
\text { Mung-6 }\end{array}$ & $\begin{array}{c}\text { BARI } \\
\text { Mung-8 }\end{array}$ & $\begin{array}{c}\text { BARI } \\
\text { Mung-6 }\end{array}$ & $\begin{array}{c}\text { BARI } \\
\text { Mung-8 }\end{array}$ & $\begin{array}{c}\text { BARI } \\
\text { Mung-6 }\end{array}$ & $\begin{array}{c}\text { BARI } \\
\text { Mung-8 }\end{array}$ \\
\hline 0 & $\begin{array}{l}1.51 \mathrm{~g} \\
(0.06)\end{array}$ & $\begin{array}{l}1.80 f \\
(0.12)\end{array}$ & $\begin{array}{l}0.31 \mathrm{~h} \\
(0.03)\end{array}$ & $\begin{array}{l}0.36 f \\
(0.02)\end{array}$ & $\begin{array}{l}0.72 d \\
(0.07)\end{array}$ & $\begin{array}{l}1.35 b \\
(0.06)\end{array}$ & $\begin{array}{l}0.40 h \\
(0.02)\end{array}$ & $\begin{array}{l}0.47 f \\
(0.06)\end{array}$ \\
\hline 100 & $\begin{array}{l}2.26 e \\
(0.03)\end{array}$ & $\begin{array}{l}3.25 d \\
(0.12)\end{array}$ & $\begin{array}{l}0.33 g \\
(0.02)\end{array}$ & $\begin{array}{l}0.39 d \\
(0.03)\end{array}$ & $\begin{array}{c}0.89 \mathrm{~cd} \\
(0.02)\end{array}$ & $\begin{array}{c}1.48 \mathrm{ab} \\
(0.05)\end{array}$ & $\begin{array}{l}0.46 \mathrm{~g} \\
(0.02)\end{array}$ & $\begin{array}{l}0.53 d \\
(0.02)\end{array}$ \\
\hline 200 & $\begin{array}{l}5.21 b \\
(0.17)\end{array}$ & $\begin{array}{l}6.17 a \\
(0.18)\end{array}$ & $\begin{array}{l}0.41 c \\
(0.05)\end{array}$ & $\begin{array}{l}0.44 a \\
(0.03)\end{array}$ & $\begin{array}{c}1.55 a b \\
(0.03)\end{array}$ & $\begin{array}{l}1.83 a \\
(0.04)\end{array}$ & $\begin{array}{l}0.53 c \\
(0.02)\end{array}$ & $\begin{array}{l}0.62 a \\
(0.06)\end{array}$ \\
\hline 300 & $\begin{array}{l}3.11 d \\
(0.25)\end{array}$ & $\begin{array}{l}4.11 c \\
(0.12)\end{array}$ & $\begin{array}{l}0.38 \mathrm{e} \\
(0.01)\end{array}$ & $\begin{array}{l}0.42 b \\
(0.01)\end{array}$ & $\begin{array}{c}1.43 a b \\
(0.06)\end{array}$ & $\begin{array}{c}1.23 b c \\
(0.06)\end{array}$ & $\begin{array}{l}0.50 e \\
(0.03)\end{array}$ & $\begin{array}{l}0.56 b \\
(0.02)\end{array}$ \\
\hline CV (\%) & \multicolumn{2}{|c|}{2.83} & \multicolumn{2}{|c|}{8.03} & \multicolumn{2}{|c|}{12.14} & \multicolumn{2}{|c|}{7.82} \\
\hline
\end{tabular}

Data are presented as mean $\pm S E(n=3)$. Data followed by same letter are not significantly different by DMRT test at $p<0.05, \mathrm{CV}, \mathrm{Co}$-efficient of variation.

and developmental processes in plants which was confirmatory to the present report, that was particularly important in regulating the stem elongation (Zhang et al., 2007). Seed priming with $\mathrm{GA}_{3}$ $(15 \mathrm{ppm})$ in $V$. radiata increased the shoot fresh weight up to $6.88 \%$ over control (Kundu et al., 2017). Miceli et al. (2019) reported that exogenous application of $\mathrm{GA}_{3}$ showed an increase of total fresh biomass by 41.1 and $40.2 \%$ as compared to controls in lettuce and rocket plants, respectively. $\mathrm{GA}_{3}$ increases plant fresh weight due to enhancing water retention in plant cells (Salisbury and Ross, 1990).

\section{Root Fresh Weight}

Foliar spray of $\mathrm{GA}_{3}$ had stimulatory effect on the root fresh weight plant $^{-1}$. Spraying of $200 \mathrm{ppm} \mathrm{GA}_{3}$ gave the highest root fresh weight $\left(0.62 \mathrm{~g} \mathrm{plant}^{-1}\right)$ from BARI Mung- 8 , and the lowest fresh weight $\left(0.40 \mathrm{~g} \mathrm{plant}^{-1}\right)$ was obtained from BARI Mung-6 at control treatment (Table 5). However, we observed genotypic variability between the varieties under $\mathrm{GA}_{3}$ treated and nontreated conditions. Application of $\mathrm{GA}_{3}$ produced the highest fresh weight in $V$. radiata (Baliah et al., 2018), pea (Lazlo, 1974), and Ixora coccinea (Gad et al., 2016). Most favorable effect on the characteristic of root length was highlighted by respective treatments of $10 \mathrm{ppm} \mathrm{GA}_{3}$ as seed priming of $V$. radiata, and treating of $V$. radiata seeds with $\mathrm{GA}_{3}$ caused an increase of the root length up to $2.60 \%$ ( 5 ppm of $\mathrm{GA}_{3}$ ) and the root fresh weight up to $4.35 \%$ (10 ppm of $\mathrm{GA}_{3}$ ) was evidenced over control (Kundu et al., 2017).

\section{Leaf Dry Weight}

Leaf dry matter was significantly influenced by the application of different concentrations of $\mathrm{GA}_{3}$. The higher dry weight of leaf $\left(0.98 \mathrm{~g} \mathrm{plant}^{-1}\right)$ was obtained from BARI Mung-8 as compared to BARI Mung-6 at 200 ppm of $\mathrm{GA}_{3}$ (Table 6). In case of control treatment, both varieties (BARI Mung- 6 and BARI Mung-8) gave the lowest values $\left(0.60\right.$ and $\left.0.69 \mathrm{~g} \mathrm{plant}^{-1}\right)$, respectively. The present findings are in agreement with the effect of $\mathrm{GA}_{3}$ at its optimum dose of 150-200 ppm for obtaining the highest leaves dry weight plant $^{-1}$ as indicated by previous workers in $V$. radiata (Renu, 2019), and in rice (Zhu et al., 1998; Thirthalingapa et al., 1999), although the highest dry weight was recorded at $125 \mathrm{ppm}$
$\mathrm{GA}_{3}$ by Akand et al. (2015) in tomato, and Saini et al. (2017) in mustard. $\mathrm{GA}_{3}$ plays a significant role in leaf expansion, resulting increased leaf dry weight of cabbage (Roy and Nasiruddin, 2011). $\mathrm{GA}_{3}$ acts as messengers for triggering metabolic activities, and accelerates plant growth and development. The significant increase of the leaf dry weight could be explained by the positive effect of photosynthetic pigments due to $\mathrm{GA}_{3}$ (Table 4) that might increase the photosynthesis and dry matter production. Nabi et al. (2014) reported that leaf area, leaf area index as well as leaf dry weight significantly increased with the application $\mathrm{GA}_{3}$ in cowpea. Foliar application of $\mathrm{GA}_{3}$ at the pre-flowering stage causes $35.5 \%$ increase in leaf area, which apparently enhances trapping of sunlight and dry matter of mustard plants (Khan et al., 1998), stimulate flowering and can cause fruit set by initiation of fruit growth, followed by pollination (Gupta and Gupta, 2005), involves in the regulation of cell division in meristematic tissues, which results in the formation of new cells (Emongor, 2007) resulting in increased plant growth (Abel and Theologis, 2010).

\section{Petiole Dry Weight}

Both varieties showed significant results at $200 \mathrm{ppm}$ concentration of the foliar application of $\mathrm{GA}_{3}$. But when the varieties are compared with one another then and there BARI Mung- 8 showed higher values than BARI Mung- 6 in every cases. The highest $\left(0.27 \mathrm{~g} \mathrm{plant}^{-1}\right)$ and lowest $\left(0.14 \mathrm{~g} \mathrm{plant}^{-1}\right)$ petiole dry weight were observed in BARI Mung- 8 and BARI Mung-6 at 200 and $0 \mathrm{ppm}$ concentrations, respectively (Table 6). The outcome is identical with Renu (2019), who stated that $\mathrm{GA}_{3}$ of 200 ppm significantly increased the petiole dry weight.

\section{Stem Dry Weight}

Stem dry weight was increased gradually by the application of $\mathrm{GA}_{3}$ from 0 to $200 \mathrm{ppm}$ concentration. The highest value $(0.38 \mathrm{~g}$ plant $^{-1}$ ) was obtained from BARI Mung-8 at 200 ppm GA . $_{3}$ In case of stem dry weight, BARI Mung- 6 gave lower values compared to BARI Mung-8 (Table 6). Our results regarding $\mathrm{GA}_{3}$ are in agreement with the previous results of Renu (2019) who found the highest stem dry weight plant $^{-1}$ in $V$. radiata treated with 200 ppm $\mathrm{GA}_{3}$ as compare to untreated control. 
TABLE 6 | Effect of $\mathrm{GA}_{3}$ on the dry matter in different plant parts of $V$. radiata varieties.

\begin{tabular}{|c|c|c|c|c|c|c|c|c|}
\hline $\mathrm{GA}_{3}(\mathrm{ppm})$ & \multicolumn{2}{|c|}{ Leaf dry weight (g plant ${ }^{-1}$ ) } & \multicolumn{2}{|c|}{ Petiole dry weight (g plant ${ }^{-1}$ ) } & \multicolumn{2}{|c|}{ Stem dry weight (g plant ${ }^{-1}$ ) } & \multicolumn{2}{|c|}{ Root dry weight (g plant ${ }^{-1}$ ) } \\
\hline 0 & $\begin{array}{l}0.60 \mathrm{~h} \\
(0.06)\end{array}$ & $\begin{array}{c}0.69 f \\
(0.06)\end{array}$ & $\begin{array}{l}0.14 \mathrm{~h} \\
(0.02)\end{array}$ & $\begin{array}{l}0.19 f \\
(0.02)\end{array}$ & $\begin{array}{l}0.25 \mathrm{~h} \\
(0.01)\end{array}$ & $\begin{array}{l}0.29 \mathrm{~g} \\
(0.01)\end{array}$ & $\begin{array}{l}0.05 \mathrm{~h} \\
(0.01)\end{array}$ & $\begin{array}{l}0.09 f \\
(0.02)\end{array}$ \\
\hline 100 & $\begin{array}{l}0.90 f \\
(0.03)\end{array}$ & $\begin{array}{l}0.92 d \\
(0.01)\end{array}$ & $\begin{array}{l}0.16 \mathrm{~g} \\
(0.01)\end{array}$ & $\begin{array}{l}0.22 d \\
(0.02)\end{array}$ & $\begin{array}{l}0.30 f \\
(0.02)\end{array}$ & $\begin{array}{l}0.32 e \\
(0.01)\end{array}$ & $\begin{array}{l}0.08 \mathrm{~g} \\
(0.02)\end{array}$ & $\begin{array}{l}0.11 d \\
(0.01)\end{array}$ \\
\hline 300 & $\begin{array}{l}0.91 e \\
(0.03)\end{array}$ & $\begin{array}{l}0.95 b \\
(0.01)\end{array}$ & $\begin{array}{l}0.21 e \\
(0.02)\end{array}$ & $\begin{array}{l}0.25 b \\
(0.01)\end{array}$ & $\begin{array}{l}0.33 d \\
(0.03)\end{array}$ & $\begin{array}{l}0.35 c \\
(0.01)\end{array}$ & $\begin{array}{l}0.10 e \\
(0.01)\end{array}$ & $\begin{array}{l}0.13 b \\
(0.02)\end{array}$ \\
\hline CV (\%) & \multicolumn{2}{|c|}{5.09} & \multicolumn{2}{|c|}{7.09} & \multicolumn{2}{|c|}{5.43} & \multicolumn{2}{|c|}{7.01} \\
\hline
\end{tabular}

Data are presented as mean $\pm S E(n=3)$. Data followed by same letter are not significantly different by DMRT test at $p<0.05, \mathrm{CV}, \mathrm{Co}$-efficient of variation.

Mukhtar and Singh (2006) reported that $\mathrm{GA}_{3}$ stimulated an increase in growth, and grain yield of cowpea. $\mathrm{GA}_{3}$ increased the total dry biomass plant ${ }^{-1}$ at all stages of growth, and the maximum total dry biomass plant $^{-1}$ was recorded with foliar spraying of $\mathrm{GA}_{3}$ at $125 \mathrm{ppm}$ in mustard (Saini et al., 2017) and tomato (Akand et al., 2015). GA 3 had significant effect on the plant dry weight where it increased the dry weight, while the highest dry weight was recorded with 33.3 ppm $\mathrm{GA}_{3}$ which was statistically close to 50 ppm GA 3 (Nabi et al., 2014). Doijode (1977) also found the highest plant dry weight in garden peas at flowering stage with foliar spraying of $30 \mathrm{ppm} \mathrm{GA}_{3}$. $\mathrm{GA}_{3}$ is responsible for prompting growth activities, increasing stem elongation and dry weight and yield (Abdel et al., 1996; Deotale et al., 1998). It may be due to greater cell division and stem elongation (longer plant), higher RWC, photosynthetic pigments, and plant biomass (fresh weights of leaves, stems, and roots) and $\mathrm{N}$ content in grains. Similar trends of better plant growth due to cell division and expansion (Roy and Nasiruddin, 2011), higher photosynthesis (Kumar et al., 2014), more total chlorophyll, carotenoid, total carbohydrates (Singh et al., 2015), higher crop growth rate (CGR), relative growth rate (RGR) (Rahman et al., 2018) was recorded in many studies. On the other hand, our study contradicts the earlier findings as nonsignificant improvement of shoot dry weight in $V$. radiata was observed by exogenous application of $\mathrm{GA}_{3}$ (Kundu et al., 2017). As compare to control, the total dry biomass of lettuce and rocket plants increased due to exogenous application of $\mathrm{GA}_{3}$ $\left(10^{-6} \mathrm{M}\right)$ by 59.9 and $59.0 \%$, respectively (Miceli et al., 2019). From different literature it can be said that the concentration of $\mathrm{GA}_{3}$ varied for obtaining the maximum dry weight might be differential plant species and contiguous environment. Hedden and Thomas (2012) also concluded the similar statement on their study.

\section{Root Dry Weight}

$\mathrm{GA}_{3}$ caused a significant increase of root dry weight plant ${ }^{-1}$ as like the previous parameter in both varieties. However, foliar application of $200 \mathrm{ppm}$ concentration $\mathrm{GA}_{3}$ recorded the highest value of root dry weight plant ${ }^{-1}\left(0.12\right.$ and $\left.0.15 \mathrm{~g} \mathrm{plant}^{-1}\right)$ in BARI Mung- 6 and BARI Mung-8, respectively. While, the lowest root dry weight $\left(0.05\right.$ and $\left.0.09 \mathrm{~g} \mathrm{plant}^{-1}\right)$ was obtained at control condition from BARI Mung-6 BARI and Mung-8, respectively (Table 6). These results are consistent with previously reported data where the highest root dry weight plant $^{-1}$ was obtained with $200 \mathrm{ppm} \mathrm{GA} 3$ in V. radiata (Renu, 2019), and with 125 ppm $\mathrm{GA}_{3}$ in tomato (Akand et al., 2015). The root dry weight was always higher in BARI Mung- 8 than in BARI Mung- 6 in this study. It has been reported that $\mathrm{GA}_{3}$ increases the root dry weight in beans (Jaques et al., 2019), Trigonella foenumgraecum (Ahmad Dar et al., 2015), the dry weight of pods in French bean (Gabal et al., 1990), and bulbs in onion (Hore et al., 1988). However, exogenous application of $\mathrm{GA}_{3}$ through seed priming in $V$. radiata did not influence the root dry weight as reported by Kundu et al. (2017), which contradicts in our findings.

The results demonstrated an increased dry matter accumulation (leaves, petioles, stems, and roots) due to $\mathrm{GA}_{3}$ treatment may be potentially attributed to the better water balance (demonstrated by higher RWC) in photosynthetic organs (Table 3), and higher photosynthetic pigments (Table 4) thus helped to maintain higher photosynthetic rate and growth. Sun (2004) reported that $\mathrm{GA}_{3}$ stimulates the production of mRNA molecules in cells which activates hydrolytic enzymes, and consequently promotes speedy growth. It is well-established that greater dry matter production and distribution significantly contributes to the yield potential of crop plants and would appear to largely account for the increased crop yields. A clear correlation between phytohormone content and the rate of dry matter accretion by the sink is recorded in many recent studies (Rahman et al., 2018; Miceli et al., 2019; Renu, 2019). PGRs have a potential role to influence the movement of photo-assimilates through their action on either sink activity and/or sink size. The rate of photo-assimilates transfer from the phloem could be adjusted by PGRs influencing phloem unloading and/or sink uptake processes (Patrick and Wareing, 1981). $\mathrm{GA}_{3}$ enhances hydrolysis of starch, fructans and sucrose into glucose and fructose molecules which provide energy via respiration, and also contribute to cell wall formation, thereby promoting cell and plant growth (Salisbury and Ross, 1990). 
TABLE 7 | Effect of $\mathrm{GA}_{3}$ on the plant height (cm), pods plant ${ }^{-1}$, pod length (cm), and grains pod ${ }^{-1}$ of $V$. radiata varieties.

\begin{tabular}{|c|c|c|c|c|c|c|c|c|}
\hline \multirow[t]{2}{*}{$\mathrm{GA}_{3}(\mathrm{ppm})$} & \multicolumn{2}{|c|}{ Plant height (cm) } & \multicolumn{2}{|c|}{ No. of pods plant ${ }^{-1}$} & \multicolumn{2}{|c|}{ Pod length (cm) } & \multicolumn{2}{|c|}{ No. of grains pod ${ }^{-1}$} \\
\hline & $\begin{array}{c}\text { BARI } \\
\text { Mung-6 }\end{array}$ & $\begin{array}{c}\text { BARI } \\
\text { Mung-8 }\end{array}$ & $\begin{array}{c}\text { BARI } \\
\text { Mung-6 }\end{array}$ & $\begin{array}{c}\text { BARI } \\
\text { Mung-8 }\end{array}$ & $\begin{array}{c}\text { BARI } \\
\text { Mung-6 }\end{array}$ & $\begin{array}{c}\text { BARI } \\
\text { Mung-8 }\end{array}$ & $\begin{array}{c}\text { BARI } \\
\text { Mung-6 }\end{array}$ & $\begin{array}{c}\text { BARI } \\
\text { Mung-8 }\end{array}$ \\
\hline 0 & $\begin{array}{l}41.00 f \\
(2.31)\end{array}$ & $\begin{array}{c}50.02 \mathrm{c} \\
(2.89)\end{array}$ & $\begin{array}{l}6.07 f \\
(0.58)\end{array}$ & $\begin{array}{l}9.84 c \\
(0.12)\end{array}$ & $\begin{array}{l}7.29 f \\
(0.58)\end{array}$ & $\begin{array}{l}7.81 d \\
(0.12)\end{array}$ & $\begin{array}{l}7.00 c \\
(0.58)\end{array}$ & $\begin{array}{c}8.01 b c \\
(0.46)\end{array}$ \\
\hline 100 & $\begin{array}{c}43.67 e \\
(1.73)\end{array}$ & $\begin{array}{c}53.10 b \\
(1.73)\end{array}$ & $\begin{array}{l}7.23 \mathrm{e} \\
(0.58)\end{array}$ & $\begin{array}{c}11.73 b \\
(0.58)\end{array}$ & $\begin{array}{l}7.69 e \\
(0.06)\end{array}$ & $\begin{array}{l}7.95 c \\
(0.58)\end{array}$ & $\begin{array}{c}8.01 b c \\
(0.12)\end{array}$ & $\begin{array}{c}9.09 a b \\
(0.12)\end{array}$ \\
\hline 200 & $\begin{array}{c}49.10 c \\
(0.58)\end{array}$ & $\begin{array}{c}62.11 \mathrm{a} \\
(1.15)\end{array}$ & $\begin{array}{c}9.04 \mathrm{~cd} \\
(0.29)\end{array}$ & $\begin{array}{c}13.81 \mathrm{a} \\
(0.58)\end{array}$ & $\begin{array}{l}7.98 \mathrm{c} \\
(0.58)\end{array}$ & $\begin{array}{l}8.91 a \\
(0.12)\end{array}$ & $\begin{array}{c}9.10 \mathrm{ab} \\
(0.58)\end{array}$ & $\begin{array}{c}10.81 a \\
(0.12)\end{array}$ \\
\hline 300 & $\begin{array}{c}45.61 d \\
(1.15)\end{array}$ & $\begin{array}{c}56.06 b \\
(1.15)\end{array}$ & $\begin{array}{l}8.30 d \\
(0.59)\end{array}$ & $\begin{array}{c}12.09 b \\
(0.33)\end{array}$ & $\begin{array}{l}7.77 e \\
(0.06)\end{array}$ & $\begin{array}{l}8.80 \mathrm{~b} \\
(0.58)\end{array}$ & $\begin{array}{l}7.22 \mathrm{c} \\
(0.46)\end{array}$ & $\begin{array}{c}9.06 a b \\
(0.29)\end{array}$ \\
\hline CV (\%) & \multicolumn{2}{|c|}{0.41} & \multicolumn{2}{|c|}{5.23} & \multicolumn{2}{|c|}{0.54} & \multicolumn{2}{|c|}{6.55} \\
\hline
\end{tabular}

Data are presented as mean $\pm S E(n=3)$. Data followed by same letter are not significantly different by DMRT test at $p<0.05$, CV, Co-efficient of variation.

\section{Plant Height}

We evaluated the effect of $\mathrm{GA}_{3}$ on the plant height which was recorded at final harvesting stage. Genetically, BARI Mung-8 was the longer plant as well as more responsive to $\mathrm{GA}_{3}$ as compare to BARI Mung-6. GA 3 had a positive effect on the plant height of both varieties, and the rate of increment was higher in BARI Mung-8 than BARI Mung-6. BARI Mung-8 treated by $\mathrm{GA}_{3}$ at $200 \mathrm{ppm}$ substantially increased the plant height (24.17\%), while the increment was only $19.75 \%$ in case of BARI Mung-6 (Table 7). Application of $\mathrm{GA}_{3}$ at $200 \mathrm{ppm}$ increased the plant height of $59.42 \%$ in $V$. radiata (Renu, 2019), $100.98 \%$ in garden pea (Singh et al., 2015), and $11.72 \%$ in tobacco plants (Wolbang and Ross, 2001). The possible reason of increased plant height could be ascribed to the favorable effects of $\mathrm{GA}_{3}$ on the physiological processes inducing cell division, increasing cell elongation, and enlargement or both due to higher RWC (Table 3) and photosynthetic pigments (Table 4). Our result is also in agreement with the findings of Hoque and Haque (2002), Abdel and Al-Rawi (2011), Keykha et al. (2014) and Raina et al. (2018) in V. radiata, Iqbal et al. (2001) in chickpea, Emongor (2007) in cowpea, Pandey et al. (2004) in pea, Deotale et al. (1998) in soybean, and Kumar et al. (2014) in tomato. The increase in plant height due to $\mathrm{GA}_{3}$ application might be had an effect on the elongation of internodes (Krishnamoorthy, 1981). If the concentration of $\mathrm{GA}_{3}$ is increased, the plant height also increased in faba bean (Omar et al., 1998). Application of $\mathrm{GA}_{3}$ resulted in increase plant height was evidenced by Chauhan et al. (2009) in black gram and horse gram, Noor et al. (2017) in French bean, Sarkar et al. (2002) in soybean. Seed priming with $\mathrm{GA}_{3}$ also increased the seedling length of many crops like V. radiata (Kundu et al., 2017), Pennisetum typhoides (Sevik and Guney, 2013), carrot, lettuce, onion, and welsh onion (Jeong et al., 2000), and Pennisetum typhoides (Gupta and Mukherjee, 1982). During priming $\mathrm{GA}_{3}$ may be influence seed germination, and growth and developmental processes of plumules and radicles regulating increase stem and root elongation. This may be attributed to the capacity of $\mathrm{GA}_{3}$ to induce mRNA synthesis pertaining to hydrolytic enzymes and to the increased cell enlargement eventually leading to increased length of internodes. Exogenous PGR enhanced plant growth by overcoming any harmful effect that may be due to changing (Yoshida and Hirasawa, 1996; Ahmad Dar et al., 2015) and functioning endogenous plant hormones.

\section{Number of Pods per Plant}

The application of $\mathrm{GA}_{3}$ showed a significant effect on the increasing number of total pods. According to inherent characteristics, the varieties differed significantly, and BARI Mung- 8 produced higher number of pods (9.84) than BARI Mung-6 (6.07) under control condition. The maximum number of pods plant ${ }^{-1}$ by applying $200 \mathrm{ppm}$ of $\mathrm{GA}_{3}$ was obtained (13.81 and 9.04) from BARI Mung-8 and BARI Mung-6, respectively (Table 8). $\mathrm{GA}_{3}$ controls the pod development in pea (Santes and Garcia-Martinez, 1995). Application of $\mathrm{GA}_{3}$ at 80 DAS increased the number of pods plant ${ }^{-1}$ in Brassica juncea (Khan et al., 1998; Saini et al., 2017). The effective rate of application on the number of pods plant ${ }^{-1}$ varied with the varieties and crop species. Abdel and Al-Rawi (2011) reported that application of $\mathrm{GA}_{3}$ at $100 \mathrm{ppm}$ in $V$. radiata plant produced the highest pods plant ${ }^{-1}(8.49 \%$ increment over control), whereas Singh et al. (2015) obtained the highest number pods plant ${ }^{-1}$ in pea with $200 \mathrm{ppm} \mathrm{GA}$. This is might be due to the genetic variability of the crops. Application of $\mathrm{GA}_{3}$ increased the vegetative growth by enhancing other growth promoting hormones resulting increased the number of pods plant $^{-1}$ in V. radiata (Abdel and Al-Rawi, 2011), and soybean (Sarkar et al., 2002). $\mathrm{GA}_{3}$ facilitates increasing the fruit bearing nodes which eventually develop into pods reducing abscission of flowers and pods in bean (Abdel-Fattah et al., 1995), increasing the number of flowers plant ${ }^{-1}$ in fenugreek and pea (Shahine et al., 1992), and hence increasing number of pods that reach maturity (Jane, 2001).

\section{Pod Length}

Pod length was significantly influenced by the application of $\mathrm{GA}_{3}$. The pod length ranges from $7.29-8.91 \mathrm{~cm}$ with different $\mathrm{GA}_{3}$ levels. In between varieties, application of $200 \mathrm{ppm} \mathrm{GA}$ produced the longest pod $(7.98$ and $8.91 \mathrm{~cm})$ in BARI Mung- 6 and BARI Mung-8, respectively. Exogenous application of $\mathrm{GA}_{3}$ 
TABLE 8 | Effect of different concentration of $\mathrm{GA}_{3}$ on 100-grain weight (g), grain yield (tha ${ }^{-1}$ ), stover yield (tha ${ }^{-1}$ ), and harvest index (\%) of $V$. radiate.

\begin{tabular}{|c|c|c|c|c|c|c|c|c|}
\hline \multirow[t]{2}{*}{$\mathrm{GA}_{3}(\mathrm{ppm})$} & \multicolumn{2}{|c|}{100 -grain weight (g) } & \multicolumn{2}{|c|}{ Grain yield $\left(\right.$ tha $\left.^{-1}\right)$} & \multicolumn{2}{|c|}{ Stover yield (tha ${ }^{-1}$ ) } & \multicolumn{2}{|c|}{ Harvest index (\%) } \\
\hline & $\begin{array}{c}\text { BARI } \\
\text { Mung-6 }\end{array}$ & $\begin{array}{c}\text { BARI } \\
\text { Mung-8 }\end{array}$ & $\begin{array}{c}\text { BARI } \\
\text { Mung-6 }\end{array}$ & $\begin{array}{c}\text { BARI } \\
\text { Mung-8 }\end{array}$ & $\begin{array}{c}\text { BARI } \\
\text { Mung-6 }\end{array}$ & $\begin{array}{c}\text { BARI } \\
\text { Mung-8 }\end{array}$ & $\begin{array}{c}\text { BARI } \\
\text { Mung-6 }\end{array}$ & $\begin{array}{c}\text { BARI } \\
\text { Mung-8 }\end{array}$ \\
\hline 0 & $\begin{array}{c}3.94 \\
(0.17)\end{array}$ & $\begin{array}{c}2.99 \\
(0.12)\end{array}$ & $\begin{array}{l}0.92 d \\
(0.06)\end{array}$ & $\begin{array}{c}1.21 b c \\
(0.06)\end{array}$ & $\begin{array}{l}0.50 \mathrm{~b} \\
(0.03)\end{array}$ & $\begin{array}{l}0.51 b \\
(0.06)\end{array}$ & $\begin{array}{c}61.11 \mathrm{c} \\
(0.58)\end{array}$ & $\begin{array}{c}\text { 70.08abc } \\
(2.89)\end{array}$ \\
\hline 100 & $\begin{array}{c}4.08 \\
(0.12)\end{array}$ & $\begin{array}{c}3.02 \\
(0.12)\end{array}$ & $\begin{array}{c}1.13 \mathrm{~cd} \\
(0.06)\end{array}$ & $\begin{array}{c}1.36 b c \\
(0.12)\end{array}$ & $\begin{array}{l}0.53 b \\
(0.02)\end{array}$ & $0.59 b(0.03)$ & $\begin{array}{c}67.48 \mathrm{abc} \\
(1.15)\end{array}$ & $\begin{array}{c}\text { 69.34abc } \\
(1.15)\end{array}$ \\
\hline 200 & $\begin{array}{c}4.16 \\
(0.06)\end{array}$ & $\begin{array}{l}3.06 \\
(0.05)\end{array}$ & $\begin{array}{c}1.42 \mathrm{ab} \\
(0.06)\end{array}$ & $\begin{array}{l}1.85 a \\
(0.06)\end{array}$ & $\begin{array}{l}0.61 b \\
(0.06)\end{array}$ & $\begin{array}{l}0.88 a \\
(0.06)\end{array}$ & $\begin{array}{c}\text { 72.48ab } \\
(1.15)\end{array}$ & $\begin{array}{c}\text { 66.66abc } \\
(3.46)\end{array}$ \\
\hline 300 & $\begin{array}{c}4.17 \\
(0.06)\end{array}$ & $\begin{array}{c}3.28 \\
(0.06)\end{array}$ & $\begin{array}{c}1.11 \mathrm{~cd} \\
(0.12)\end{array}$ & $\begin{array}{c}1.65 a b \\
(0.06)\end{array}$ & $\begin{array}{l}0.56 \mathrm{~b} \\
(0.03)\end{array}$ & $\begin{array}{l}0.61 b \\
(0.06)\end{array}$ & $\begin{array}{c}63.41 \mathrm{bc} \\
(5.77)\end{array}$ & $\begin{array}{c}74.63 a \\
(2.31)\end{array}$ \\
\hline CV (\%) & \multicolumn{2}{|c|}{9.13} & \multicolumn{2}{|c|}{15.81} & \multicolumn{2}{|c|}{10.01} & \multicolumn{2}{|c|}{5.08} \\
\hline
\end{tabular}

Data are presented as mean $\pm S E(n=3)$. Data followed by same letter are not significantly different by DMRT test at $p<0.05$, CV, Co-efficient of variation.

increased the pod length more in BARI Mung- 8 than in BARI Mung-6 (Table 7). The pod length is increased due to application of $\mathrm{GA}_{3}$ as reported by Bhadra (2004), Renu (2019) in V. radiata, Emongor (2007) in cowpea, and Singh et al. (2015) in pea, although the effect of $\mathrm{GA}_{3}$ depends on the particular species and surrounding factors (Hedden and Thomas, 2012). Such as, 125 ppm $\mathrm{GA}_{3}$ produced the longest siliquae plant ${ }^{-1}$ of mustard (Saini et al., 2017), maximum fruit length of tomato (Akand et al., 2015). Pod development is the resultant effect of active cell division (Inglese et al., 2005), more plasticity of cell walls (Stoddart, 1981; Salisbury and Ross, 1990) which is induced by the $\mathrm{GA}_{3}$. The enhanced water uptake by the leaves (Table 3) possibly led to enhanced leaves expansion (exhibited by fresh and dry weights of leaves), hence the increased pod length observed in this study.

\section{Number of Grains per Pod}

Various concentrations of $\mathrm{GA}_{3}$ have a significant effect on the number of grains pod ${ }^{-1}$. The number of grains pod $^{-1}$ increased with the application of $\mathrm{GA}_{3}$ up to $200 \mathrm{ppm}$, and thereafter decreased in both the varieties. Plants treated with $200 \mathrm{ppm}$ of $\mathrm{GA}_{3}$ produced the highest number of grains $\operatorname{pod}^{-1}(9.10$ and 10.81), and the lowest values (7.00 and 8.01) were found with untreated control plants from BARI Mung-6 and BARI Mung-8, respectively (Table 7). The increment rate due to $\mathrm{GA}_{3}$ was higher in BARI Mung-8. The result is accordance with the findings of Abdel and Al-Rawi (2011) and Renu (2019) in V. radiata, Emongor (2007) in cowpea, and Singh et al. (2015) in pea, who reported that application of $\mathrm{GA}_{3}$ at $200 \mathrm{ppm}$ produced the highest number of grains pod ${ }^{-1} \cdot \mathrm{GA}_{3}$ stimulates flowering which enhances fruit setting positively (Gupta and Gupta, 2005). The number of grains pod ${ }^{-1}$ significantly increased with using various concentration of $\mathrm{GA}_{3}$ on soybean (Rahman et al., 2004), okra (Kumer et al., 1996), and linseed (Rastogi et al., 2013).

\section{0-Grain Weight}

The effect of $\mathrm{GA}_{3}$ on the 100-grain weight was insignificant in both the varieties, although the 100-grains weight gradually increased with the increasing concentration of $\mathrm{GA}_{3}$. However, the highest 100-grain weight (4.17 g) was obtained with the $\mathrm{GA}_{3}$ of $300 \mathrm{ppm}$ in BARI Mung-6. On the other hand, the lowest
(2.99 g) 100-grain weight was obtained in BARI Mung-8 under control condition. BARI Mung- 6 always produced bolder grain than BARI Mung-8 among all the treatments (Table 8). Similar results were also reported by Bhadra (2004), Renu (2019) in $V$. radiata, and Emongor (2007) in cowpea. Exogenous application of $\mathrm{GA}_{3}$ progressively increased the grain weight in different crops in previous studies (Groot et al., 1987; Lee, 1990; Emongor, 2007; Tiwari et al., 2011). Bora and Sharma (2006) obtained the highest 100 -grain weight at $250 \mathrm{ppm} \mathrm{GA}_{3}$ in pea. The result of this study is approximately similar to the above reports.

\section{Yield}

\section{Grain Yield}

Grain yield is an important parameter, and application of suitable concentration of $\mathrm{GA}_{3}$ influenced grain yield of $V$. radiata significantly. The varietal difference in case of grain yield was significant, and BARI Mung- 8 produced higher grain yield plant $^{-1}$. The highest grain yield $\left(1.85\right.$ tha $\left.^{-1}\right)$ was obtained by applying $200 \mathrm{ppm}$ of $\mathrm{GA}_{3}$, and the lowest grain yield (0.92 tha $^{-1}$ ) was obtained from control treatments (Table 8). The highest grain is obtained with foliar spraying of $200 \mathrm{ppm}$ $\mathrm{GA}_{3}$ which may be due to higher values of RWC (Table 3), higher contents of photosynthetic pigments (Table 4) better translocation of photosynthates and metabolites (fresh and dry weights; Tables 5, 6), more $\mathrm{N}$ uptake (demonstrated by higher $\mathrm{N}$ content in grain; Table 9) and yield contributing traits. The results of our investigation are in line with the findings obtained by Renu (2019) who found that plants treated with 200 ppm GA produced the highest yield among the $\mathrm{GA}_{3}$ treated plants in $V$. radiata. Foliar application of $100 \mathrm{ppm}$ of $\mathrm{GA}_{3}$ increased the grain yield per plant in rice (Awan and Alizai, 1989), okra (Kumer et al., 1996), mustard (Saini et al., 2017), and tomato (Groot et al., 1987; Jong et al., 2009; Akand et al., 2015). In the present study, the best treatment was $200 \mathrm{ppm}$ of $\mathrm{GA}_{3}$, where treated plants tended to increase grain yield by 54.35 and $52.89 \%$ in BARI Mung- 6 and BARI Mung-8, respectively. In very recent study, Tasnim et al. (2020) concluded that $100 \mathrm{ppm} \mathrm{GA}_{3}$ increased the grain yield of $41.25 \%$ in BARI Mung- 8 variety. However, $\mathrm{GA}_{3}$ causes a substantial increase of grain yield in different crops 
has also been reported by Bhadra (2004), Abdel and Al-Rawi (2011), Keykha et al. (2014), and Rahman et al. (2018) in $V$. radiata, Noor et al. (2017) in French bean, Swain et al. (1997), and Sharma et al. (2006) in pea, Emongor (2007) in cowpea, Sarkar et al. (2002) in soybean, Tomar and Ramgiry (1997), and Khan et al. (2006) in tomato. Exogenous application of $\mathrm{GA}_{3}$ may help to redistribute assimilates toward the shoot apex and young leaves, aiding in the utilization of nitrogen, and thus resulting in increased yield of mustard (Khan et al., 2002). The effective partitioning and translocation of assimilates from source to sink in the field crops are promoted by PGRs (Solaimalai et al., 2001; Senthil et al., 2003). GA 3 also increased the yield of beans might be attributed through increase of pod length and number, water content in pod, fresh weight, and reduce wilting of pods in French beans (Jane, 2001), increase leaf number, leaf area index, and leaf area duration in faba beans (Harb, 1992), more dry matter accumulation in peach fruit (Patrick and Wareing, 1981). Hence, application of $\mathrm{GA}_{3}$ as foliar may be a valuable approach for boosting the plant growth and yield of $V$. radiata.

\section{Stover Yield}

The present study clearly indicated that different levels of $\mathrm{GA}_{3}$ have the potentiality to influence the stover yield of $V$. radiata in both varieties. The highest stover yield of 0.88 tha $^{-1}$ was recorded at $200 \mathrm{ppm}$ of $\mathrm{GA}_{3}$ from BARI Mung-8, and the lowest stover yield as 0.50 tha $^{-1}$ at $0 \mathrm{ppm}$ of $\mathrm{GA}_{3}$ from BARI Mung-6 (Table 8). It might be due to more efficient diversion of energy from source to sink. This result is in agreement with the findings of Hoque (2001), Gadi et al. (2017), Rahman et al. (2018), Renu (2019), Tasnim et al. (2020) who concluded that the straw yield of $V$. radiata was significantly increased with increasing levels of growth regulator $\mathrm{GA}_{3}$. $\mathrm{GA}_{3}$ increased the vegetative growth (increased fresh and dry weights), and reproductive growth (higher number of pods and pod lengths) which might be enhanced the elevated stover weight per plant. In this background, $\mathrm{GA}_{3}$ increased TDM, LAI, RGR, and NAR which tended to increase plant biomass (Sarkar et al., 2002; Rahman et al., 2004; Azizi et al., 2012; Noor et al., 2017).

\section{Harvest Index}

Significant influence in harvest index is occurred by application of $\mathrm{GA}_{3}$. There is a significant variation occur in both varieties with using $\mathrm{GA}_{3}$. The highest harvest index (74.63\%) was found from BARI Mung- 8 by applying $\mathrm{GA}_{3}$ at $300 \mathrm{ppm}$. In contrary, BARI Mung-6 gave the lowest harvest index (61.11\%) from control treatment (Table 8). These results were adhered to the results of Uddin (1999), Rahman et al. (2018), Renu (2019), and Tasnim et al. (2020) in V. radiata, Noor et al. (2017) in French bean, Emongor (2007) in cow pea, Khan (1997) in mustard, Ahmad Dar et al. (2015) in Trigonella foenum-graecum, who concluded that application of $\mathrm{GA}_{3}$ increased the harvest index, though its concentration was varied for different crops. In this experiment, $\mathrm{GA}_{3}$ increased the harvest index statistically. Nabi et al. (2014) reported that foliar spraying $\mathrm{GA}_{3}$ at $33.3 \mathrm{ppm}$ increased the harvest index $(22.45 \%)$ in cowpea that was identical to 50 ppm GA 3 (22.07\%), and the lowest harvest index $(18.76 \%)$ was noticed in control treatment.

\section{Correlation of Grain Yield With Growth and Yield Attributes}

Association between two traits represents the performance of the treatments under such situations for which the data was recorded. In the study, the $\mathrm{PH}$ showed non-significant relationship with LDW, significant negative relationship with GPP and HGW, whereas other traits exhibited significant positive correlation (Figure 3). Likewise, NPPP showed non-significant relationship with LDW, significant negative relationship with HGW, but other traits exhibited significant positive correlation. The results clearly indicated that the HGW decrease with increasing NPPP. The PL showed positive significant correlation with almost all the traits except GPP, whereas HGW and LDW showed negative and positive non-significant effect, respectively. The GPP showed significant negative correlation with almost all the study traits except NPPP but exhibited non-significant effect with HGW and LDW. The HGW showed non-significant negative correlation with almost all the study traits except $\mathrm{PH}$ and NPPP which showed significant negative relationship. The LDW exhibited a significant positive correlation only with SDW, RDW, and GY, whereas others parameters showed non-significant relation. The SDW showed significant positive correlation with almost all the study traits except GPP and HGW where exposed significant negative and non-significant relationship, respectively. Similar results were observed in case of RDW. The StY demonstrated non-significant negative association with HGW and LDW, whereas significant negative association found with GPP, and others traits were associated positive significantly. GY indicated a significant positive correlation with all traits except GPP and HGW which sowed negative but significant and non-significant correlation, respectively. Positive correlation among yield parameters like NPPP, HSW, SWPP, and GY were reported by Ullah (2006) in cowpea, and Azizi et al. (2012) in soybean. A positive correlation among $\mathrm{PH}$, number of branches plant $^{-1}$, NPPP, HSW, and GY of chickpea was also reported by Hasanuzzaman et al. (2007). Noor (2014) found strong positive correlation among the leaf area index, total dry matter, CGR, NAR, fresh pod yield plant ${ }^{-1}$, and fresh fodder yield plant ${ }^{-1}$ of French bean. In another study, Emongor (2007) observed linear regression with significant positive correlation between $\mathrm{GA}_{3}$ levels and grain yield in cowpea.

\section{Quality Traits \\ Nitrogen Content (\%)}

Gibberellic acid induced the metabolic activities, and regulated nitrogen utilization that reflected plant growth and development (Sure et al., 2012). V. radiata plants treated with foliar $\mathrm{GA}_{3}$ significantly increased the $\mathrm{N}$ content in grains in our study (Table 9). However, the highest amount of $\mathrm{N}$ (4.57 and 4.76\%) was obtained in grains with the foliar spraying of $\mathrm{GA}_{3}$ at 200 ppm level in BARI Mung-6 and BARI Mung-8, and increment rates were 25.2 and $28.3 \%$ over control, respectively. Grains of BARI Mung- 8 contained higher $\mathrm{N}$ content as well as higher increment due to $\mathrm{GA}_{3}$ than BARI Mung-6. This might be due to genetic makeup of the variety of $V$. radiata. The results of our study were strongly supported by Renu (2019), who concluded 
TABLE 9 | Effect of different concentration of $\mathrm{GA}_{3}$ on $\mathrm{N}$ and protein content (\%) of $V$. radiata varieties.

\begin{tabular}{|c|c|c|c|c|c|c|c|c|}
\hline \multirow[t]{2}{*}{$\mathrm{GA}_{3}(\mathrm{ppm})$} & \multicolumn{2}{|c|}{$\mathbf{N}(\%)$} & \multicolumn{2}{|c|}{ Increase over control (\%) } & \multicolumn{2}{|c|}{ Protein (\%) } & \multicolumn{2}{|c|}{ Increase over control (\%) } \\
\hline & $\begin{array}{c}\text { BARI } \\
\text { Mung-6 }\end{array}$ & $\begin{array}{c}\text { BARI } \\
\text { Mung-8 }\end{array}$ & $\begin{array}{c}\text { BARI } \\
\text { Mung-6 }\end{array}$ & $\begin{array}{c}\text { BARI } \\
\text { Mung-8 }\end{array}$ & $\begin{array}{c}\text { BARI } \\
\text { Mung-6 }\end{array}$ & $\begin{array}{c}\text { BARI } \\
\text { Mung-8 }\end{array}$ & $\begin{array}{c}\text { BARI } \\
\text { Mung-6 }\end{array}$ & $\begin{array}{c}\text { BARI } \\
\text { Mung-8 }\end{array}$ \\
\hline 0 & $\begin{array}{l}3.65 c \\
(0.23)\end{array}$ & $\begin{array}{l}3.71 c \\
(0.12)\end{array}$ & - & - & $\begin{array}{c}23.52 \mathrm{c} \\
(0.58)\end{array}$ & $\begin{array}{c}24.23 c \\
(0.02)\end{array}$ & - & - \\
\hline 100 & $\begin{array}{l}3.91 b \\
(0.17)\end{array}$ & $\begin{array}{l}3.98 b \\
(0.12)\end{array}$ & 7.1 & 7.3 & $\begin{array}{c}25.55 b \\
(0.58)\end{array}$ & $\begin{array}{c}26.41 b \\
(0.58)\end{array}$ & 8.6 & 9.0 \\
\hline 200 & $\begin{array}{l}4.57 a \\
(0.04)\end{array}$ & $\begin{array}{l}4.76 a \\
(0.46)\end{array}$ & 25.2 & 28.3 & $\begin{array}{c}27.69 \mathrm{a} \\
(0.58)\end{array}$ & $\begin{array}{c}28.66 \mathrm{a} \\
(1.15)\end{array}$ & 17.7 & 18.3 \\
\hline 300 & $\begin{array}{l}3.96 b \\
(0.06)\end{array}$ & $\begin{array}{c}4.08 a b \\
(0.06)\end{array}$ & 8.5 & 10.0 & $\begin{array}{c}26.13 a b \\
(0.58)\end{array}$ & $\begin{array}{c}27.73 \mathrm{ab} \\
(0.58)\end{array}$ & 11.1 & 14.4 \\
\hline CV (\%) & \multicolumn{2}{|c|}{7.22} & \multicolumn{2}{|c|}{-} & \multicolumn{2}{|c|}{10.01} & \multicolumn{2}{|c|}{-} \\
\hline
\end{tabular}

Data are presented as mean $\pm S E(n=3)$. Data followed by same letter are not significantly different by DMRT test at $p<0.05$, CV, Co-efficient of variation.

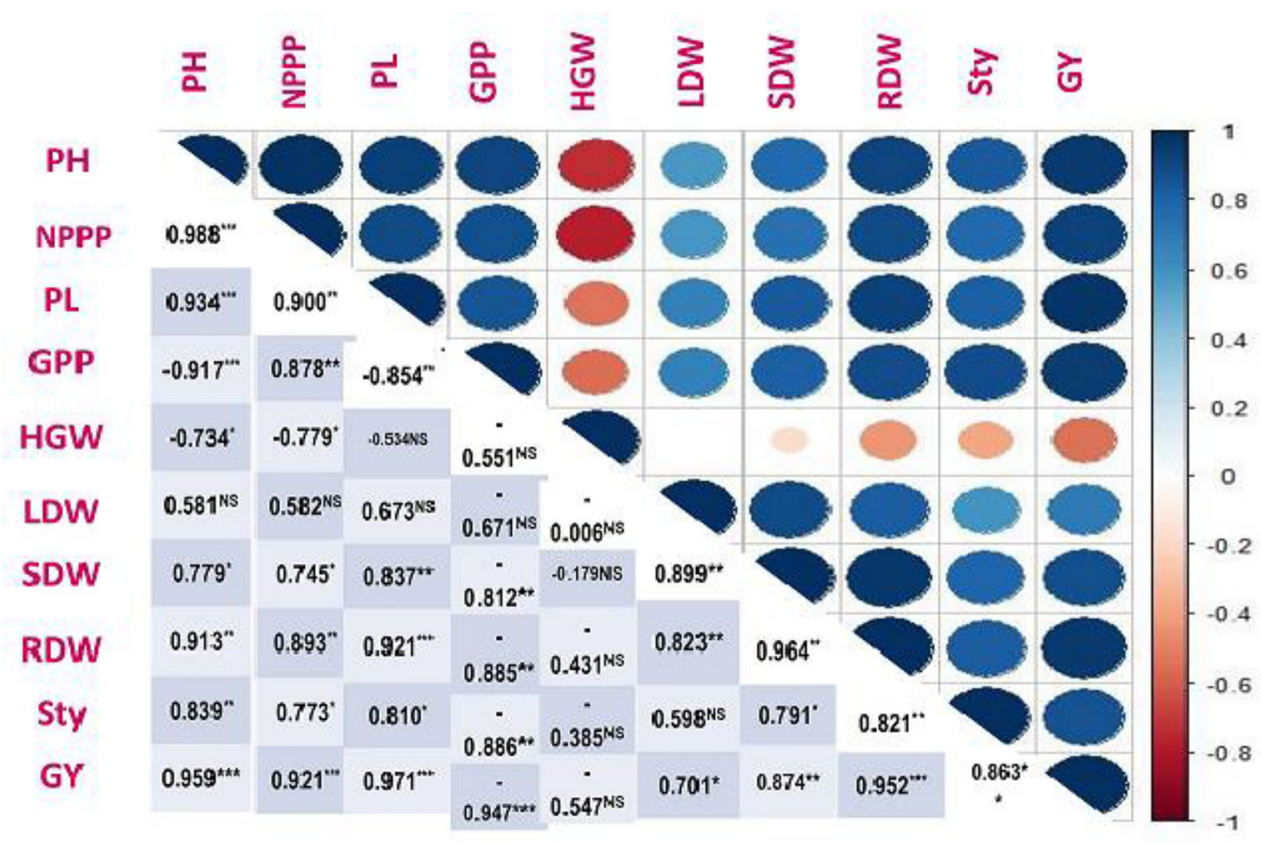

FIGURE 3 | Correlation coefficients of grain yield on growth traits and yield components in V. radiata. According to the color scale, the darker positive scale represents most of the treatment responses, while the darker negative stripes show the least response. The dark blue color showed a high positive association and the dark red color showed a high negative correlation between traits. Similarly, as the color intensity decreases, the treatments show moderate performance in both the positive and negative ranges (PH, Plant height; NPPP, Number of pods per plant; PL, Pod length; GPP, Grains per pod; HGW, Hundred grain weight; LDW, Leaf dry weight; SDW, Stem dry weight; RDW, Root dry weight; StY, Straw yield; GY, Grain yield). *significant at 0.05, ${ }^{\star *}$ significant at 0.01 , and ${ }^{* \star *}$ Significant at 0.001\% levels, NS, Non-significant.

that foliar application of $200 \mathrm{ppm} \mathrm{GA} 3$ produced the highest amount of $\mathrm{N}$ content in $V$. radiata grain. These finding were also closer to the finding of Kumar et al. (2018), who reported that $150 \mathrm{ppm} \mathrm{GA}_{3}$ generated the highest $\mathrm{N}$ content in $V$. radiata leaves. It might be due to fact that $\mathrm{GA}_{3}$ increases $\mathrm{N}$ use efficiency through nitrogen metabolism and nitrogen redistribution (Khan et al., 2002). The enhancement of N, P and $\mathrm{K}$ contents due to application of $\mathrm{GA}_{3}$ has earlier been reported by Sayed (2001), Soad (2005), and Sure et al. (2012). Miceli et al. (2019) reported that $\mathrm{GA}_{3}\left(10^{-6} \mathrm{M}\right)$ significantly increased the $\mathrm{N}$ use efficiency in lettuce and rocket over control by 27.1 and $30.7 \%$, respectively. Exogenous $\mathrm{GA}_{3}$ enhanced the plant growth which increases the nitrogen requirements of the plant, and increases the $\mathrm{N}$ content in grains. It is reported that $\mathrm{GA}_{3}$ enhances the nitrate reductase activity that leads to increase nitrogen utilization (Ahmad Dar et al., 2015; Zhang et al., 2017, Miceli et al., 2019). Foliar application of $\mathrm{GA}_{3}$ enhanced the enzyme activity in crop plants (Broughton, 1968; Crozier and Turnbull, 1984), and increased the membrane permeability (Wood and Paleg, 1972, 1974) that might facilitate uptake and use of mineral 
nutrients (Al-Wakeel et al., 1995; Ansari, 1996; Khan et al., 1998; Ahmad Dar et al., 2015). GA 3 is also known to stimulate mobilization of foods and minerals in storage cells of cereal grains (Akazawa and Miyata, 1982).

\section{Protein Content}

The protein content in grain is an important quality parameter in legumes, and plant hormones have a significant role on the protein content in $V$. radiata grains. The results revealed that the protein content increased significantly over control with increasing $\mathrm{GA}_{3}$ concentration, and the highest values (27.69 and $28.66 \%$ ) were recorded with spraying $200 \mathrm{ppm}$ of $\mathrm{GA}_{3}$ in BARI Mung- 6 and BARI Mung-8, respectively (Table 9). These results are supported by several studies reporting that $\mathrm{GA}_{3}$ markedly increased the protein content in the grains of $V$. radiata (Chen et al., 1987; Mubeen et al., 2014; Baliah et al., 2018; Kumar et al., 2018; Renu, 2019), blackgram (Dheeba et al., 2015), chickpea (Mazid, 2014), garden pea (Mishrinky et al., 1990; Singh et al., 2015), and soybean (Khafagy, 1995; Khatun et al., 2016). Exogenous application of $\mathrm{GA}_{3}$ has been shown to promote the synthesis of protein in many crops (Johri and Varner, 1968; Pain and Dutta, 1977; Mozer, 1980), and consequently increased the vigorous plant growth. $\mathrm{GA}_{3}$ may induce the development of xylem and phloem, and consequently increase the flow and deposition of assimilation products in seeds (Secer, 1989).

\section{CONCLUSIONS}

$\mathrm{GA}_{3}$ has a potential role for escalating RWC, photosynthetic pigments, dry matter production, yield contributing characteristics, yield and quality ( $\mathrm{N}$ and protein content) of $V$. radiata varieties. Plants treated with 200 ppm $\mathrm{GA}_{3}$ as foliar spraying maintained the highest RWC and photosynthetic pigments, and showed the highest dry matter in different plant parts, and thereby fabricated the highest values of yield contributing characteristics and yield of $V$. radiata varieties. Similar trends were also observed in case of nitrogen and protein content in grains with $\mathrm{GA}_{3}$ treatments. Grain yield indicated a significant positive correlation with all traits except GPP and

\section{REFERENCES}

Abd El-Fattah, M. A. (1997). Effect of phosphorus, boron, GA3 and their interaction on growth, flowering, pod setting, abcission, and both green pod and seed yields of broad bean (Vicia faba L.) plants. Alexandria J. Agril. Res. 42, 311-322.

Abdel, C. G., and Al-Rawi, I. M. T. (2011). Response of mungbean (Vigna radiata L., Wilczek) to gibberellic acid (GA3) rates and varying irrigation frequencies. Int. J. Biosci. 1, 85-92.

Abdel, G. B. A., El-Shourbagy, M. N., and El-Naggar, R. A. (1996). Effect of IAA and GA3 on flax (Lmumusii aiissium L.) seed yield and their metabolic constituents. Egyptian J. Bot. 35, 1-9.

Abdel-Fattah, M. A., Farag, R. S., and Abdel-Bar, F. M. (1995). Effects of some growth regulators on plant growth of bean (Phaseoulus vulgaris L.). Agric. Res. Rev. 63, 97-111.

Abdel-Mouty, M. M., and El-Greadly, N. H. M. (2008). The productivity of two okra cultivars as affected by gibberellic acid, organic $\mathrm{N}$, rock phosphate and feldspar application. J. Appl. Sci. Res. 4, 627-636.
TGW. Considering all morpho-physiology and quality traits, BARI Mung- 8 performed better than BARI Mung-6, and the previous one is more responsive to $\mathrm{GA}_{3}$ than the later one. Based on the findings, it is recommended, therefore, to use $200 \mathrm{ppm}$ $\mathrm{GA}_{3}$ for obtaining the maximum yield of $V$. radiata varieties.

\section{DATA AVAILABILITY STATEMENT}

The original contributions presented in the study are included in the article/supplementary material, further inquiries can be directed to the corresponding authors.

\section{AUTHOR CONTRIBUTIONS}

MSI conceived and designed research, coordinated for publication, and wrote the manuscript. $\mathrm{MKH}, \mathrm{BI}$, and NR conducted the experiment. $\mathrm{MKH}$ contributed to analyze the data and drafting of the manuscript. MRI, MAH, MC, AU, HS, MA, $\mathrm{SF}, \mathrm{CB}, \mathrm{FC}$, and $\mathrm{ME}$ reviewed and editing the manuscript. AE coordinated manuscript submission and processing. All authors read and approved the manuscript.

\section{FUNDING}

This work was supported by University Grants Commission (UGC), Bangladesh (Grant \# 4829), through Institute of Research and Training (IRT), HSTU, Dinajpur, Bangladesh.

\section{ACKNOWLEDGMENTS}

The authors are grateful to Dr. Shafiqul Islam Sikdar, Chairman and Professor, Department of Agronomy, HSTU for providing research materials and assistance. The authors also acknowledge to Amena, Anas, Anik, Asraf, Bilkas, Choyon, Debash, Foysal, Keya, Mosabbirul, Nupur, Parvin, Rafi, Rafia, Ratul, Rajju, Sanchita, Sazedul, Shariful, Sumona, Tartila, and Tonusree, the students of L4SII/2017, Faculty of Agriculture, HSTU, Dinajpur for their supports as a part of practical class (Project).
Abel, S., and Theologis, A. (2010). "Odyssey of auxin," in Perspective in Biology, eds M. Estelle, D. Weijers, K. Ljung, and O. Leyser (Berlin: Cold Spring Harbor Press; Leibniz-Institut Fuer), 1-13.

Afroz, S., Mohammad, F., Hayat, S., and Siddiqui, M. H. (2005). Exogenous application of gibberellic acid counteracts the ill effects of sodium chloride in mustard. Turkish J. Biol. 29, 233-236.

Aftab, T., Khan, M. M. A., Idrees, M., Naeem, M., Singh, M., and Ram, M. (2010). Stimulation of crop productivity, photosynthesis and artemisinin production in Artemisia annua L. by triacontanol and gibberellic acid application. J. Plant Interac. 5, 273-281. doi: 10.1080/17429141003647137

Agriculture Information Service (AIS) (2019). Krishi Diary (In Bangla). Khamarbari; Dhaka: Agriculture Information Service; Ministry of Agriculture of the People's Republic of China, 14.

Ahmad Dar, T., Uddin, M., Khan, M. A., Ali, A., Hashmi, N., and Idrees, M. (2015). Cumulative effect of gibberellic acid and phosphorus on crop productivity, biochemical activities and trigonelline production in Trigonella foenum-graecum L. Cogent Food Agric. 1:995950. doi: 10.1080/23311932.2014.9 95950 
Ahmad, M. S. A., Hossain, M., Ijaz, S., and Alvi, A. K. (2008). Photosynthetic performance of two mungbean (Vigna radiata) cultivars under lead and copper stress. Int. J. Agric. Biol. 10, 167-172.

Akand, M. H., Khairul Mazed, H. E. M., Pulok, M. A. I., Chowdhury, M. S. N., and Moonmoon, J. F. (2015). Growth and yield of tomato (Lycopersicon esculentum Mil L.) as influenced by different level of gibberellic acid application. Int. J. Appl. Res. 1, 71-74.

Akazawa, T., and Miyata, S. (1982). Biosynthesis and secretion of a-amylase and other hydrolases in germinating cereal seeds. Essays Biochem. 18, 40-78.

Aldesuquy, H. S., and Ibrahim, A. H. (2001). Interactive effect of seawater and growth bio-regulators on water relations, absicisic acid concentration and yield of wheat plants. J. Agron. Crop Sci. 187, 185-193. doi: 10.1046/j.1439-037x.2001. 00522.x

Al-Shaheen, M. R., Soh, A., and Al-Samarai, G. F. (2014). Growth responses of corn (Zea mays L.) to proline and gibberellic acid spray under different irrigation levels. Int. J. Bot. Res. 4, 7-16.

Al-Wakeel, S. A. M., Hamed, A. A., and Dadoura, S. S. (1995). Interactive effects of water stress and gibberellic acid on mineral composition of fenugreek plant. Egypt J. Physiol. Sci. 18, 269-282.

Al-Whaibi, M. H., Siddiqui, M. H., Al-Amri, A., and Basalah, M. O. (2010). Performance of faba bean under calcium and gibberellic acid application. Int. J. Plant Develop. Biol. 4, 60-63.

Ansari, H. R. (1996). Effect of some phytohormones and NPK on growth and metabolism of mustard (Ph.D. thesis). Aligarh Muslim University, Aligarh, India.

Arteca, R. N. (1996). Plant Growth Substances: Principles and Applications. New York, NY: Chapman and Hall.

Asahina, M., Iwai, H., Kikuchi, A., Yamaguchi, S., Kamiya, Y., Kamada, H., et al. (2002). Gibberellin produced in the cotyledon is required for cell division during tissue reunion in the cortex of cut cucumber and tomato hypocotyls. Plant Physiol. 129, 201-210. doi: 10.1104/pp.010886

Ashour, N. I., Neumann, D., and zur Nieden, U. (1973). Gibberellic acid induced changes in the ultrastructure of chloroplasts and the content of chlorophyll in leaves of dwarf maize (Zea mays L.). Biochem. Physiol. Pflanzen 164, 402-413. doi: 10.1016/S0015-3796(17)30709-6

Atteya, K. G., Esmail, A., Genaidy, E., and Zahran, H. A. (2018). Chemical constituents and yield of Simmondsia chinensis plants as affected by foliar application of gibberellic acid and zinc sulphate. Bio. Res. 15, 1528-1541.

Awan, I., and Alizai, H. K. (1989). Effect of plant growth regulators on ripening, grain development and rice quality. Int. Rice Res. Newslet. 149, 30-31.

Azizi, K., Moradii, J., Heidari, S., Khalili, A., and Feizian, M. (2012). Effect of different concentrations of gibberellic acid on seed yield and yield components of soybean genotypes in summer intercropping. Int. J. Agri. Sci. 2, 291-301.

Baliah, N. T., Sheeba, P. C., and Mallika, S. (2018). Encouraging effect of gibberellic acid on the growth and biochemical characters of green gram (Vigna radiata $\mathrm{L}$.). J. Global Biosci. 7, 5522-5529.

Bangladesh Agricultural Research Institute (BARI) (2019). Krishi Projuktir Hatboi (Handbook on Agro-Technology). 8th ed. Gazipur: Bangladesh Agricultural Research Institute, 74-76.

Barr, H. D., and Weatherley, P. E. (1962). A re-examination of the relative turgidity technique for estimating water deficit in leaves. Aust. J. Biol. Sci. 15, 413-428. doi: $10.1071 /$ BI9620413

Bhadra, A. K. (2004). Effect of GA3 on growth and yield attributes of mungbean (Ph.D. thesis). Department of Crop Botany, Bangladesh Agricultural University, Mymensingh, Bangladesh.

Black, C. A. (1965). Methods of Soil Analysis Part 1. Agronomy Monograph 9. Madison, WI: ASA Madison.

Bora, R. K., and Sharma, C. M. (2006). Effect of gibberellic acid and clycocel on growth, yield and protein content of pea. Asian J. Plant Sci. 5, 324-330. doi: 10.3923/ajps.2006.324.330

Bray, R. H., and Kurtz, L. T. (1945). Determination of total, organic, and available forms of phosphorus in soils. Soil Sci. 59, 39-45. doi: 10.1097/00010694-194501000-00006

Bremner, J. M., and Mulvaney, C. S. (1982). Methods of Soil Analysis. Part 2. Chemical and Microbiological Properties. Madison, WI: Soil Science Society of America, 595-624.
Broughton, W. J. (1968). Influence of gibberellic acid on nucleic acid synthesis in dwarf pea internodes. Biochem. Biophys. Acta 155, 308-310. doi: 10.1016/0005-2787(68)90364-X

Chauhan, J. S., Tomar, Y. K., Singh, I. K., Ali, S., and Debarati, T. (2009). Effects of growth hormones on seed germination and seedling growth of black gram and horse gram. J. Am. Sci. 5, 79-84.

Chauhan, J. S., Tomar, Y. K., Badoni, A., Singh, N. I., Ali, S., and Debarati, L. (2010). Morphology, germination and early seedling growth in Phaseolus mungo L. with reference to the influence of various plant growth substances. J. Am. Sci. 6, 34-41.

Chen, S. L., Breene, W. M., and Schowalter, C. (1987). Effects of growth regulators on yield and quality of mungbean sprouts grown in an automatically controlled chamber. J. Food Q. 10, 219-238. doi: 10.1111/j.1745-4557.1987.tb00814.x

Crozier, A., and Turnbull, C. G. N. (1984). Gibberellins: biochemistry and action in extension growth. What's New Plant Physiol. 15, 9-12.

Deotale, R. D., Mask, V. G., Sorte, N. V., Chimurkar, B. S., and Yerne, A. Z. (1998). Effect of GA3 and IAA on morpho-physiological parameters of soybean. J. Soils Crops 8, 91-94.

Dheeba, B., Selvakumar, S., Kannan, M., and Kannan, K. (2015). Effect of gibberellic acid on black gram (Vigna mungo) irrigated with different levels of saline water. Res. J. Pharma. Biol. Chem. Sci. 6, 709-720.

Doijode, S. P. (1977). Effect of growth regulators on growth and yield of Garden pea (Pisum sativum L.). Mysore J. Agric. Sci. 11:114.

Donald, C. M. (1963). Competition among crop and pasture plants. Adv. Agron 15, 1-118. doi: 10.1016/S0065-2113(08)60397-1

El Karamany, M. F., Sadak, M. S., and Bakry, B. A. (2019). Synergistic effect of indole acetic acid and gibberellic acid on mung bean grown under sandy soil conditions. J. Appl. Sci. 19, 718-724. doi: 10.3923/jas.2019.718.724

El-Tohamy, W. A., El-Abagy, H. M., Badr, M. A., Abou-Hussein, S. D., Helmy, Y. I., and Shafeek, M. R. (2015). Effects of yeast extract and GA3 on water status, growth, productivity and quality of sweet potato grown in sandy soils. Int. J. Environ. 04, 256-261.

Emongor, V. E. (2004). Effects of gibberellic acid on postharvest quality and vaselife life of gerbera cut flowers (Gerbera jamesonii). J. Agron. 3, 191-195. doi: 10.3923/ja.2004.191.195

Emongor, V. E. (2007). Gibberellic acid (GA3) influence on vegetative growth, nodulation and yield of cowpea (Vigna unguiculata L. Walp). J. Agron. 6, 509-517. doi: 10.3923/ja.2007.509.517

Faizanullah, Bano, A., and Nosheen, A. (2010). Role of plant growth regulators on oil yield and biodiesel production of linseed (Linum usitatissimum L.). J. Chem. Soc. Pak. 32, 668-671.

Fertilizer Recommendation Guide (FRG) (2012). "Agro-ecological regions of Bangladesh," in Fertilizer Recommendation Guide-2012, eds A. A. Hassan, M. Jahiruddin, S. Noor, M. J. U. Sarker, A. L. Shah, M. M. K. Khan, S. M. Bokhtiar, M. A. Quddus, M. N. Hasan, M. S. Razia, and M. A. Satter (Dhaka: Bangladesh Agricultural Research Council), 251.

Firmino da Costa, J. C., José da Silva, D., Gustavo de Luna Souto, A., Sofiatti, V., Rosado, L. D. S., João de Lima Neto, A., et al. (2017). Physiological aspects in cotton cultivars in response to application leaf gibberellic acid. Afr. J. Agril. Res. 12, 270-278. doi: 10.5897/AJAR2016.11663

Fleet, C. M., and Sun, T. P. (2005). A DELLAcate balance: the role of gibberellin in plant morphogenesis. Curr. Opin. Plant Biol. 8, 77-85. doi: 10.1016/j.pbi.2004.11.015

Fox, R. L., Olson, R. A., and Rhoades, H. F. (1964). Evaluating the sulfur status of soil by plants and soil tests. Soil Sci. Am. Proc. 28, 243-246. doi: 10.2136/sssaj1964.03615995002800020034x

Frauque, A., Haraguchi, T., Hirota, O., and Rahman, M. A. (2000). Growth analysis, yield, and canopy structure in maize, mungbean intercropping. $\mathrm{Bu}$. Inst. Trop. Agric. 23, 61-69.

Gabal, G. M., Oben, G., and Marcell, R. (1990). Effect of GA3 on morphophysiological characters and yield of kidney beans (Phaseolus vulgaris). J. Agron. Crop Sci. 160, 94-101. doi: 10.1111/j.1439-037X.1988.tb00301.x

Gad, M. M., Abdul-Hafeez, E. Y., and Ibrahim, O. H. M. (2016). Foliar application of salicylic acid and gibberellic acid enhances growth and flowering of Ixora coccinea L. plants. Plant Prod. Mansoura Univ. 7, 85-91. doi: $10.21608 /$ jpp.2016.43477

Gadi, P., Dawson, J., and Shankar, M. (2017). Effect of different organic manures, inorganic fertilizers and growth regulator on yield attributes and 
yield of greengram (Vigna radiata L.). Int. J. Curr. Res. 12, 1567-1572. doi: 10.15740/HAS/AU/12

Garg, J., and Kumar, A. (2012). Effect of various organic nutrients on growth, biomass yield and hydrocarbon production of Euphorbia lathyris L., a hydrocarbon yielding plant. Int. J. Life Sci. Pharma. Res. 2, 83-99.

Ghodrat, V., Moradshahi, A., Rousta, M. J., and Karampour, A. (2013). Improving yield and yield components of rice (Oryza sativa L.) by indolebutyric acid (IBA), gibberellic acid (GA3) and salicylic acid (SA) pre-sowing seed treatments. Am. J. Agric. Environ. Sci. 13, 872-876. doi: 10.5829/idosi.aejaes.2013.13.06.11010

Gomez, K. A., and Gomez, A. A. (1984). Statistical Procedures for Agriculture Research. Loss Banos: International Rice Research Institute, 139-240.

Groot, S. P. C., Bruinsma, J., and Karssen, C. M. (1987). The role of endogenous gibberellin in seed and fruit development of tomato: studies with a gibberellin deficit mutant. Plant Physiol. 71, 184-190. doi: 10.1111/j.1399-3054.1987.tb02865.x

Gupta, N. K., and Gupta, S. (2005). "Growth regulators," in Plant Physiology, eds N. K. Gupta and S. Gupta (New Delhi: Oxford and IBH Publishing), 286-349.

Gupta, P., and Mukherjee, D. (1982). Influence of GA3 pre-soaking of seeds on biochemical changes in seedling parts of Pennisetum typhoides rich. Proc. Indian Natl. Sci. Acad. B 48, 642-648.

Hameed, M., Sultana, B., Anwar, F., Aslam, M., Mushtaq, M., and Munir, H. (2015). Changes in proximate composition, biochemical and antioxidant attributes of broccoli (Brassica oleracea L.) in relation to foliar application of selected plant growth ragulators. Pak. J. Bot. 47, 1685-1691.

Hammad, S. A. R., and Ali, O. A. M. (2014). Physiological and biochemical studies on drought tolerance of wheat plants by application of amino acids and yeast extract. Ann. Agril. Sci. 59, 133-145. doi: 10.1016/j.aoas.2014.06.018

Harb, E. Z. (1992). Effect of soaking seeds in some growth regulators and micronutrients on growth, some chemical constituents and yield of faba beans and cotton plants. Bull. Faculty Agric. Univ. Cairo 43, 429-452.

Hasanuzzaman, M., Karim, M. F., Fattah, Q. A., and Nahar, K. (2007). Yield performance of chickpea varieties following application of growth regulator. Ame-Eura. J. Sci. Res. 2, 117-120.

Hedden, P., and Phillips, A. L. (2000). Gibberellin metabolism: new insights revealed by the genes. Trends Plant Sci. 5, 523-530. doi: 10.1016/S1360-1385(00)01790-8

Hedden, P., and Thomas, S. G. (2012). Gibberellin biosynthesis and its regulation. Biochem. J. 444, 11-25. doi: 10.1042/BJ20120245

Hoque, M. M. (2001). Effect of gibberellic acid (GA3) on growth and yield of mungbean (Vigna radiata) (Ph.D. thesis). Department of Crop Botany, Bangladesh Agricultural University, Mymensingh, Bangladesh.

Hoque, M. M., and Haque, M. S. (2002). Effects of gibberllic acid (GA3) on physiological contributing characters of mungbean (Vigna radiata L.). Pak. J. Biol. Sci. 5, 401-403. doi: 10.3923/pjbs.2002.401.403

Hore, J. K., Paria, N. C., and Sen, S. K. (1988). Effect of pre-sowing seed treatments on germination, growth, and yield of Allium cepa var. Red Globe. Harayana J. Hort. Sci. 17, 83-87.

Hossain, M. I., Mannan, M. A., and Karim, M. A. (2015). Salicylic acid and gibberellic acid ameliorates the adverse effects of salinity on chickpea. Bangladesh Agron. J. 18, 81-88. doi: 10.3329/baj.v18i1. 25571

Inglese, P., Chessa, I., Lamantia, T., and Nieddu, G. (2005). Evolution of endogenous gibberellin at different stage of flowering in relation to return bloom of cactus pear. Sci. Hort. 71, 45-51. doi: 10.1016/S0304-4238(97) 00139-8

Iqbal, H. F., Tahir, A., Khalid, M. N., Haque, I. I., and Ahmad, A. N. (2001). Response of chickpea (Cicer arietinum L.) growth towards the foliar application of gibberellic acid at different stages. Pak. J. Biol. Sci. 4, 433-434. doi: 10.3923/pjbs.2001.433.434

Islam, M. S., El-Sabagh, A., Hasan, K., Akhter, M., and Barutçular, C. (2017b). Growth and yield response of mungbean (Vigna radiata L.) as influenced by sulphur and boron application. Sci. J. Crop Sci. 6, 153-160. doi: $10.14196 /$ sjcs.v6i1.2383

Islam, M. S., Hasan, K., Sarkar, N. A. A., El-Sabagh, A., Rashwan, E., and Barutçular, C. (2017a). Yield and yield contributing characters of mungbean as influenced by zinc and boron. Sci. J. Agril. Adv. 6, 391-397. doi: 10.14196/aa.v6i1.2362
Islam, M. S., Hasan, K., Shaddam, O., and El-Sabagh, A. (2017c). Effect of storage periods and containers on the germinablity of mungbean seeds. Sci. J. Agril. Adv. 6, 418-424. doi: 10.14196/aa.v6i7.2468

Jane, A. (2001). Effect of benzyladenine and gibberellins on yield components, yield and the postharvest shelf life of French beans (Phaseolus vulgaris L.) (Ph.D. thesis). Department of Crop Science, University of Nairobi, Nairobi, Kenya.

Jaques, L. B. A., Carvalho, I. R., Szareski, V. J., Pimentel, J. R., Troyjack, C., Dellagostin, S. M., et al. (2019). Gibberellic acid utilization in seeds and plants of beans: effect on growth and seeds physiological quality. J. Agril. Sci. 11, 541-547. doi: $10.5539 /$ jas.v11n2p541

Jeong, Y., Kang, S. M., Cho, J. L., and Jeong, Y. O. (2000). Germination of carrot, lettuce, onion and welsh onion seeds are affected by priming chemicals at various concentrations. Korean J. Hort. Sci. Technol. 18, 93-97.

Johri, M. M., and Varner, J. E. (1968). Enhancement of RNA synthesis in isolated pea nuclei by gibberellic acid. Proc. Natl. Acad. Sci. U.S.A. 59, 269-279. doi: 10.1073/pnas.59.1.269

Jong, M. D., Mariani, C., and Vriezen, W. H. (2009). The role of auxin and gibberellin in tomato fruit set. J. Exp. Bot. 60, 1523-1532. doi: 10.1093/jxb/erp094

Kaya, C., Tuna, A. L., and Alves, A. A. C. (2006). Gibberellic acid improves water deficit tolerance in maize plants. Acta Physiol. Planta 28, 331-337. doi: $10.1007 /$ s11738-006-0029-7

Keykha, M., Ganjali, H. R., and Mobasser, H. R. (2014). Effect of salicylic acid and gibberellic acid on some characteristics in mungbean (Vigna radiata). Int. J. Biosci. 5, 70-75. doi: 10.12692/ijb/5.11.70-75

Khafagy, M. A. (1995). Effects of growth substances, biological boron and their combination on soybean plants under nitrogen levels. J. Agric. Sci. Mansoura Univ. 20, 4641-4658.

Khan, M. N., Siddiqui, M. H., Mohammad, F., Naeem, M., and Khan, M. M. A. (2010). Calcium chloride and gibberellic acid protect linseed (Linum usitatissimum L.) from $\mathrm{NaCl}$ stress by inducing antioxidative defence system and osmoprotectant accumulation. Acta Physiol. Planta 32, 121-132. doi: 10.1007/s11738-009-0387-z

Khan, M. S. K. (1997). Effect of different levels of nitrogen on growth, yield and quality of wheat (Ph.D. thesis). Department of Agronomy, Bangladesh Agricultural University, Mymensingh, Bangladesh.

Khan, N. A., Ansari, H. R., and Saniullah (1998). Effect of gibberellic acid spray during ontogeny of mustard on growth, nutrient uptake and yield characteristics. J. Agron. Crop Sci. 181, 61-73. doi: 10.1111/j.1439-037X.1998.tb00399.x

Khan, N. A., Mir, R., Khan, M., and Javid, S. (2002). Effects of gibberellic acid spray on nitrogen yield efficiency of mustard grown with different nitrogen levels. Plant Growth Regul. 38, 243-247. doi: 10.1023/A:1021523707239

Khan, M. M. A., Gautam, C., Mohammad, F., Siddiqui, M. H., Naeem, M., and Khan, M. N. (2006). Effect of gibberellic acid spray on performance of tomato. Turk. J. Biol. 30, 11-16.

Khatun, S., Roy, T. S., Haque, M. N., and Alamgir, B. (2016). Effect of plant growth regulators and their time of application on yield attributes and quality of Soybean. Int. J. Plant Soil Sci. 11, 1-9. doi: 10.9734/IJPSS/2016/25981

Krishnamoorthy, H. N. (1981). Plant Growth Substances. New Delhi: McGraw Hill.

Kumar, A., Biswas, T. K., Singh, N., and Lal, E. P. (2014). Effect of gibberellic acid on growth, quality and yield of tomato (Lycopersicon esculentum Mil L.). IOSR J. Agril. Vetr. Sci. 7, 28-30. doi: 10.9790/2380-07742830

Kumar, R., Yadav, R. K., Sharma, N., Yadav, A., and Nehal, N. (2018). Influence of plant growth regulators on biochemical changes of mungbean (Vigna radiata $\mathrm{L}$. Wilczek). J. Pharmacog. Phytochem. 1, 386-389.

Kumer, S., Singh, P., Katiyar, R. P., Vaish, C. P., and Khan, A. A. (1996). Beneficial effect of some growth regulators on the seeds of okra (Abelmoschus esculentus L.) under field conditions. Seed Res. 24, 11-14.

Kundu, S., Das, B., and Yonzone, R. (2017). Effect of different hydro and osmopriming materials on germination and seedling growth of mung bean. Int. J. Chem. Stud. 5, 99-103.

Lazlo, L. (1974). Effect of GA3 spraying on plant height and on number and average weight of pods with developed seeds of pea (Pisum sativum L.). Legume Res. $10,49-52$.

Lee, H. S. (1990). Effect of pre-sowing seed treatments with GA3 and IAA on flowering and yield components in groundnuts. Korean J. Crop Sci. 35, 1-9. 
Lichtenthaler, H. K., and Buschmann, C. (2001). "Chlorophylls and carotenoids: measurement and characterization by UV-VIS spectroscopy," in Current Protocols in Food Analytical Chemistry, eds R. E. Wrolstand, T. E. Acree, H. An, E. A. Decker, M. H. Penner, et al. (New York, NY: John Wiley and Sons), F4.3.1-F4.3.8.

Lindsay, W. L., and Norvell, W. A. (1978). Development of a DTPA soil test for $\mathrm{Zn}, \mathrm{Fe}, \mathrm{Mn}$, and $\mathrm{Cu}$. Soil Sci. Soc. Am. J. 42, 421-428. doi: 10.2136/sssaj1978.03615995004200030009x

Maggio, A., Barbieri, G., Raimondi, G., and De Pascale, S. (2010). Contrasting effects of GA3 treatments on tomato plants exposed to increasing salinity. J. Plant Growth Regul. 29, 63-72. doi: 10.1007/s00344-009-9114-7

Mazid, M. (2014). Seed priming application of gibberellic acid on growth, biochemical, yield attributes and protein status of chickpea (Cicer arietinum L. cv. DCP 92-3). Int. J. Gene. Eng. Biotechnol. 5, 17-22.

Miceli, A., Moncada, A., Sabatino, L., and Vetrano, F. (2019). Effect of gibberellic acid on growth, yield, and quality of leaf lettuce and rocket grown in a floating system. Agron 9:382. doi: 10.3390/agronomy9070382

Mishrinky, J. F., Nl-Fadlay, K. A., and Badwai, M. A. (1990). Effect of gibberellic acid and chloromequat (CCC) on growth, yield and quality of pea. Bull. Faculty Agril. Univ. Cairo 41, 785-797.

Mozer, T. J. (1980). Control of protein synthesis in barley aleurone layers by the plant hormones, gibberellic acid and abscisic acid. Cell 20, 479-485. doi: 10.1016/0092-8674(80)90634-0

Mubeen, B. R., Shamim, M., Khan, A. H., Singh, A. K., Singh, S. P., et al. (2014). Response of mungbean (Vigna radiata L.) to rhizobium inoculation and growth regulators on biochemical changes and yield. Environ. Ecol. 33, 105-109.

Mukhtar, F. B., and Singh, B. B. (2006). Influence of photoperiod and gibberelic acid (GA3) on the growth and flowering of cowpea (Vigna unguiculata (L.) Walp). J. Food Agric. Env. 4, 201-203.

Nabi, A. J. M. N., Hasan, M. M., Alam, M. S., Islam, M. S., and Islam, M. R. (2014). Responses of gibberelic acid (GA3) on growth and yield of cowpea cv. BARI Falon-1 (Vigna unguiculata L.). J. Environ. Sci. Natu. Resour. 7, 7-12. doi: $10.3329 /$ jesnr.v7i2.22196

Nehal, K., Khan, A., Sharma, N., Tripathi, S. K., and Singh, M. (2018). Role of GA3, $\mathrm{SA}$ and ABA on growth and yield of Indian mustard [Brassica juncea (L.) czern. \& coss.] under rainfed condition. J. Pharmacog. Phytochem. 2, 199-203.

Noble, T. J., Tao, Y., Mace, E. S., Williams, B., Jordan, D. R., Douglas, C. A., et al. (2018). Characterization of linkage disequilibrium and population structure in a mungbean diversity panel. Front. Plant Sci. 8:2102. doi: $10.3389 /$ fpls.2017.02102

Noor, F. (2014). Physiological, biochemical and yield attributes of French bean (Phaseolus vulgaris $\mathrm{L}$.) in response to the application of growth regulators (Ph.D. thesis). Department of Botany, Jahangirnagar University, Dhaka, Bangladesh.

Noor, F., Hossain, F., and Umme Ara, U. (2017). Effects of gibberellic acid (GA3) on growth and yield parameters of French bean (Phaseolus vulgaris L.). J. Asiat. Soc. Bangladesh Sci. 43, 49-60. doi: 10.3329/jasbs.v43i1.46243

Omar, N. M., Kandil, M. M., and Hussain, M. M. (1998). Some effect of water deficit and gibberellic acid on growth photosynthetic pigments and chemical status of Vicia faba plants. Egypt. J. Agron. 11, 43-52.

Onanuga, A. O., Jiang, P., and Adl, S. (2012). Effect of phytohormones, phosphorus and potassium on cotton varieties (Gossypium hirsutum) root growth and root activity grown in hydroponic nutrient solution. J. Agric. Sci. 4, 93-110. doi: $10.5539 /$ jas.v4n2p157

Page, A. L., Miller, R. H., and Keeney, D. R. (1982). Methods of Soil Analysis. Part 2. 2nd ed. Madison, WI: American Society of America.

Pain, S. K., and Dutta, J. K. (1977). Studies on growth and metabolism of Zea mays L. I. The effect of application of gibberellic acid on the growth and metabolism of seedlings. Indian Biol. 9, 38-43.

Pandey, A. K., Tiwari, S. K., Singh P. M., and Rai, M. (2004). Effect of GA3 and NAA on vegetative growth, yield and quality of Garden pea (Pisum sativum L. ssp. Hortense asch and graebn). Veg. Sci. 31, 63-65.

Patrick, J., and Wareing, P. F. (1981). "Hormonal control of assimilate movement and distribution," in Aspects and Prospects of Plant Growth Regulators, Monograph 6, ed B. Jeffcoat (Wantage: British Plant Growth Regulator Group), 65-84.

Pazoki, A. R., Rezaei, H., Habibi, D., and Paknejad, F. (2012). Effect of drought stress, asscorbate and gibberellin foliar application on some morphological traits, RWC and cell membrane stability of Thyme (Thymus vulgaris L.). Iranian J. Agron. Plant Breed. 8, 1-13.

Pazuki, A., Sedghi, M., and Fatemeh Aflaki, F. (2013). Enteraction of salinity and phytohormones on wheat photosynthetic traits and membrane stability. Agriculture 59, 33-41. doi: 10.2478/agri-2013-0004

Piper, C. S. (1966). Soil and Plant Analysis. Adelaide University Press. Available online at: https://www.adelaide.edu.au/library/

Rahman, A. B. M., Khan, M., Hasan, M. M., Banu, L. A., and Howlader, M. H. K. (2018). Effect of foliar application of gibberellic acid on different growth contributing characters of mungbean. Prog. Agric. 29, 233-238. doi: 10.3329/pa.v29i3.40008

Rahman, M. S., Islam, M. A. T. N., and Karim, M. A. (2004). Influence of GA3 and $\mathrm{MH}$ and their time of spray on dry matter accumulation and growth attributes of soybean. Pak. J. Biol. Sci. 7, 1851-1857. doi: 10.3923/pjbs.2004.1851.1857

Raina, S. K., Govindasamy, V., Kumar, M., Singh, A. K., Rane, J., and Minhas, P. S. (2016). Genetic variation in physiological responses of mungbeans (Vigna radiata (L.) Wilczek) to drought. Acta Physiol. 38:263. doi: 10.1007/s11738-016-2280-x

Raina, S. K., Yadav, P. S., Singh, A. K., Raskar, N., Rane, J., and Minhas, P. S. (2018). Exogenous gibberellic acid does not induce early flowering in mungbeans [Vigna radiata (L.) Wilczek.]. Legume Res. 4037, 653-657. doi: 10.18805/LR-4037

Rastogi, A., Siddiqui, A., Mishra, B. K., Srivastava, M., Pandey, R., Misra, P., et al. (2013). Effect of auxin and gibberellic acid on growth and yield components of linseed (Linum usitatissimum L.). Crop Breed. App. Biotech. 13, 136-143. doi: 10.1590/S1984-70332013000200006

Renu, N. A. (2019). Alleviation of salt stress through gibberellic acid (GA3) on mungbean (Ph.D. thesis). Department of Agronomy, Hajee Mohammad Danesh Science and Technology University, Dinajpur, Bangladesh.

Roy, R., and Nasiruddin, K. M. (2011). Effect of different level of GA3 on growth and yield of cabbage. J. Env. Sci. Nat. Resour. 4, 79-82. doi: 10.3329/jesnr.v4i2.10138

Saini, P. K., Yadav, R. K., and Pratap, M. (2017). Effect of foliar application of GA3 on yield and quality of Indian mustard [Brassica juncea (L.) Czern. \& Coss.] under sodic soil. Int. J. Curr. Microbiol. App. Sci. 6, 4156-4159. doi: 10.20546/ijcmas.2017.612.477

Salisbury, F. B., and Ross, C. W. (1990). Plant Physiology. 4th Edn. Belmont, CA: Wadworth Publ. Co. Inc.

Santes, C. M., and Garcia-Martinez, J. L. (1995). Effect of the Growth Retardands 3, 5-dioxo-4-butyryl- cyclohexane carboxylic acid ethyl ester, acylcyclohexanedione compound, on fruit growth and gibberellin content of pollinated and unpollinated ovaries in pea. Plant Physiol. 108, 517-523. doi: 10.1104/pp.108.2.517

Sardoei, A. S. (2014). Gibberellic acid and benzyl adenine foliar sprays increase offsets in Aloe barbadensis. Europ. J. Exp. Biol. 4, 646-650.

Sarkar, P. K., Haque, M. S., and Karim, M. A. (2002). Growth analysis of soybean as influenced by GA3 and IAA and their frequency of application. J. Agron. 1, 123-126. doi: 10.3923/ja.2002.123.126

Sayed, M. (2001). Effect of some agriculture treatment on growth and chemical composition of some woody trees seedlings (Ph.D. thesis). Faculty of Agriculture, Minia University, Minya, Egypt.

Secer, M. (1989). Dogal Büyüme Düzenleyicilerin (Bitkisel hormonlarin) senescence in arabidopsis. Trends Plant Sci. 6, 272-278.

Senthil, A., Djanaguiraman, M., and Chandrababu, R. (2003). Effect of root dipping of seedlings with plant growth regulators and chemicals on yield and yield components of rice (Oryza sativa L.) transplanted by broadcast method. Madras Agric. J. 90, 383-384.

Sevik, H., and Guney, K. (2013). Effects of IAA, IBA, NAA, and GA3 on rooting and morphological features of Melissa officinalis L. stem cuttings. Sci. World J. 1:909507. doi: 10.1155/2013/909507

Shahine, A. H., El-Desouky, S. A., Abdi El-Dayem, H. M., and Ali, W. (1992). Response of fenugreek (Trigonella foenum-graecum L.) and pea (Pisum sativum L.) to foliar spray with some PGRs. II-flowering, dry weight, seed production and its organic matter content. Ann. Agril. Sci. 30, 755-775.

Sharma, K., Kaur, H., and Thind, S. K. (2006). Kinetin and triacontanol effects on leaf characteristics, nitrate reductase activity, nodulation and yield in soybean Glycine max (L.) Merrill under reduced light intensity. Environ. Ecol. $24,426-429$. 
Siddiqui, M. H., Khan, M. N., Mohammad, F., and Khan, M. M. A. (2008). Role of nitrogen and gibberellin (GA3) in the regulation of enzyme activities and in osmoprotectant accumulation in Brassica juncea L. under salt stress. J. Agron. Crop Sci. 194, 214-224. doi: 10.1111/j.1439-037X.2008. 00308.x

Singh, M., John, S. A., Rout, S., and Patra, S. S. (2015). Effect of GA3 and NAA on growth and quality of garden pea (Pisum sativum L.) cv. Arkel. Bioscan 10, 381-383.

Soad, M. M. I. (2005). Response of vegetative growth and chemical composition of Jojoba seedlings to some agriculture treatments (Ph.D. thesis). Faculty of Agriculture, Minia University, Minia, Egypt.

Solaimalai, A., Sivakumar, C., Anbumani, S., Suresh, T., and Arumugam, K. (2001). Role of plant growth regulators in rice production: a review. Agric. Rev. $22,33-40$.

Soliman, A. S. (2020). Plant Growth Hormones. Intech Open.

Sponsel, V. M., and Hedden, P. (2004). "Gibberellin biosynthesis and inactivation," in Plant Hormones-Biosynthesis, Signal Transduction, Action!, 3rd Edn., ed P. J. Davies (Dordrecht: Kluwer Academic Publishers), 63-94.

Stoddart, J. L. (1981). "Leaf senescence," in Aspects and Prospects of Plant Growth Regulators, Monograph 6, ed B. Jeffcoat (Wantage, NJ: British Plant Growth Regulator Group), 51-63.

Sun, T. (2004). "Gibberellin signal transduction in stem elongation and leaf growth," in Plant Hormones, Biosynthesis, Signal Transduction, Action, ed P. J. Davies (Dordrecht: Kluwer Academic Publishers), 304-320.

Sure, S., Arooie, H., and Azizi, M. (2012). Influence of plant growth regulators (PGRs) and planting method on growth and yield in oil pumpkin (Cucurbita pepo var. styriaca). Notulae Sci. Biologi. 4, 101-107. doi: 10.15835/nsb427566

Swain, S. M., Reid, J. B., and Kamiya, Y. (1997). Gibberellins are required for embryo growth and seed development in pea. Plant J. 12, 1329-1338. doi: 10.1046/j.1365-313x.1997.12061329.x

Taiz, L., and Zeiger, E. (2006). Plant Physiology, 4th Edn. Sunderland, MA: Sinauer Associates.

Taiz, L., and Zeiger, E. (2010). "Gibberellins: regulators of plant height," in Plant Physiology, ed E. Zeiger (Sunderland, MA: Sinauer Associates, Incorporated), 461-493.

Tasnim, S., Sikdar, M. S. I., Islam, M. S., Rahman, M. R., and Alam, M. J. (2020). Response of mungbean growth and yield to GA3 rate and time of application. Asian J. Crop Soil Sci. Plant Nutr. 01, 28-36. doi: 10.18801/ajcsp.010219.05

Thaltooth, A. T., Tawfik, M. M., and Mohamed, H. M. (2006). A comparative study on the effect of foliar application of zinc, potassium and magnesium on growth, yield and some chemical constituents of mungbean plants grown under water stress conditions. World J. Agril. Sci. 2, 37-46.

Thirthalingapa, B., Reddy, B. G. S., Kulkarni, R. S., Prasad, T. G., and Murthy, R. A. K. (1999). Genotypic response to exogenous application of gibberellic acid on CMS lines of rice (Oryza sativa L.). Mysore J. Agril. Sci. 33, 145-150.

Tiwari, D. K., Pandey, P., Giri, S. P., and Dwivedi, J. L. (2011). Effect GA3 and other plant growth regulators on hybrid rice seed production. Asian J. Plant Sci. 10, 133-139. doi: 10.3923/ajps.2011.133.139
Tomar, I. S., and Ramgiry, S. R. (1997). Effect of growth regulator on yield and yield attributes in tomato Lyropersicon esculentum Mill. Adv. Plant Sci. 10, 29-31.

Uddin, M. H. (1999). Effect of plant growth regulators on flowering, pod set and yield attributes in mungbean (Ph.D. thesis). Department of Crop Botany, Bangabandhu Sheikh Mujibur Rahman Agricultural University, Gazipur, Bangladesh.

Ullah, M. J. (2006). Physiological and biochemical responses of cowpea (Vigna unguiculata (L.) Walp.) following the application of growth regulators (Ph.D. thesis). Department of Botany, Jahangirnagar University, Dhaka, Bangladesh.

Vichnevetskaia, K. D., and Roy, D. N. (1999). Oxidative stress and antioxidative defense with an emphasis on plants antioxidants. Environ. Rev. 7, 31-51. doi: 10.1139/a99-004

Wolbang, C. M., and Ross, J. J. (2001). Auxin promotes gibberellin biosynthesis in decapitated tobacco plants. Planta 214, 153-157. doi: 10.1007/s004250100663

Wood, A., and Paleg, L. G. (1972). The influence of GA3 on the permeability of model membrane systems. Plant Physiol. 50, 103-108. doi: 10.1104/pp.50.1.103

Wood, A., and Paleg, L. G. (1974). Alteration of liposomal membrane fluidity by gibberellic acid. Aust. J. Plant Physiol. 1, 31-40. doi: 10.1071/PP9740031

Yagoob, H., and Yagoob, M. (2014). The effects of water deficit stress on protein yield of mung bean genotypes. Peak J. Agril. Sci. 2, 30-35.

Yoshida, I., and Hirasawa, E. (1996). Gibberellin induces endopeptidase activity in detached cotyledons of Pisum sativum. J. Plant Growth Regul. 19, 55-60. doi: 10.1007/BF00024402

Yuan, L., and $\mathrm{Xu}, \mathrm{D}$. Q. (2001). Stimulation effect of gibberellic acid short-term treatment on leaf photosynthesis related to the increase in RuBisCO content in broad bean and soybean. Photosyn. Res. 68, 39-47. doi: 10.1023/A:1011894912421

Zhang, Y., Ni, Z., Yao, Y., Nie, X., and Sun, Q. (2007). Gibberellins and heterosis of plant height in wheat (Triticum aestivum L.). BMC Gene 8, 40-49. doi: 10.1186/1471-2156-8-40

Zhang, M., Liu, M., Zhang, Y., Ji, Y., Zhao, M., and Wu, Z. (2017). Effect of different plant growth regulator added in nutrient solution on growth and development of summer tomato seedling. North Hortic. 6, 8-13.

Zhu, Y. Y., Liang, X. H., and Gao, L. (1998). The effect of spraying with water soluble GA3 in hybrid rice seed production. Zhejiang Nongye Kexue 3, 129-130.

Conflict of Interest: The authors declare that the research was conducted in the absence of any commercial or financial relationships that could be construed as a potential conflict of interest.

Copyright (c) 2021 Islam, Hasan, Islam, Renu, Hakim, Islam, Chowdhury, Ueda, Saneoka, Ali Raza, Fahad, Barutçular, Çig, Erman and El Sabagh. This is an openaccess article distributed under the terms of the Creative Commons Attribution License (CC BY). The use, distribution or reproduction in other forums is permitted, provided the original author(s) and the copyright owner(s) are credited and that the original publication in this journal is cited, in accordance with accepted academic practice. No use, distribution or reproduction is permitted which does not comply with these terms. 